\title{
PTEN Inhibition in Human Disease Therapy
}

\author{
Rafael Pulido ${ }^{1,2}$ \\ 1 Biomarkers in Cancer Unit, Biocruces Health Research Institute, 48903 Barakaldo, Spain; \\ rpulidomurillo@gmail.com \\ 2 IKERBASQUE, Basque Foundation for Science, 48013 Bilbao, Spain
}

Received: 10 January 2018; Accepted: 28 January 2018; Published: 30 January 2018

\begin{abstract}
The tumor suppressor PTEN is a major homeostatic regulator, by virtue of its lipid phosphatase activity against phosphatidylinositol 3,4,5-trisphosphate [PI(3,4,5)P3], which downregulates the PI3K/AKT/mTOR prosurvival signaling, as well as by its protein phosphatase activity towards specific protein targets. PTEN catalytic activity is crucial to control cell growth under physiologic and pathologic situations, and it impacts not only in preventing tumor cell survival and proliferation, but also in restraining several cellular regeneration processes, such as those associated with nerve injury recovery, cardiac ischemia, or wound healing. In these conditions, inhibition of PTEN catalysis is being explored as a potentially beneficial therapeutic intervention. Here, an overview of human diseases and conditions in which PTEN inhibition could be beneficial is presented, together with an update on the current status of specific small molecule inhibitors of PTEN enzymatic activity, their use in experimental models, and their limitations as research or therapeutic drugs.
\end{abstract}

Keywords: small molecule PTEN inhibitor; neuroregeneration; tissue injury; wound healing; response to infection; infertility; stem-cells; cancer; diabetes; pain relief

\section{Introduction}

PTEN is a highly conserved dual-specificity protein tyrosine phosphatase (PTP) of ubiquitous expression, with capacity to dephosphorylate both inositol lipids and proteins (Figure 1). PTEN protein presents an N-terminal PTP catalytic domain followed by a C2-lipid-binding domain, which are essential for the stability and function of the enzyme and for the association of PTEN to membranes. At the C-terminus, PTEN possesses a disordered C-terminal tail with regulatory functions. Several lipidand protein-binding motifs, distributed at different PTEN regions, facilitate PTEN recruitment to the proximity of substrates at several subcellular compartments [1,2]. Recently, PTEN isoforms with extended N-termini and common PTP and C-terminal domains, which distribute at different intracellular and extracellular locations, have been described, and their physiologic expression and function are under scrutiny [3].

A distinctive feature of PTEN, in comparison with other PTPs, is the presence of a wider and negatively charged catalytic pocket with capability to accommodate both phospho-inositol lipids and phospho-amino acids, which explains in part PTEN substrate specificity [4]. PTEN dephosphorylates in vivo the lipid second messengers phosphatidylinositol 3,4,5-trisphosphate $[\mathrm{PI}(3,4,5) \mathrm{P} 3]$ and phosphatidylinositol 3,4-bisphosphate [PI(3,4)P2] to produce phosphatidylinositol 4,5-bisphosphate [PI $(4,5) \mathrm{P} 2]$ and phosphatidylinositol 4-phosphate [PI(4)P], opposing the action of the class I PI3Ks [5-7]. This unique activity makes PTEN a major homeostatic regulator and tumor suppressor protein, whose function is absent or defective in a wide variety of tumors as a result of somatic alterations. 

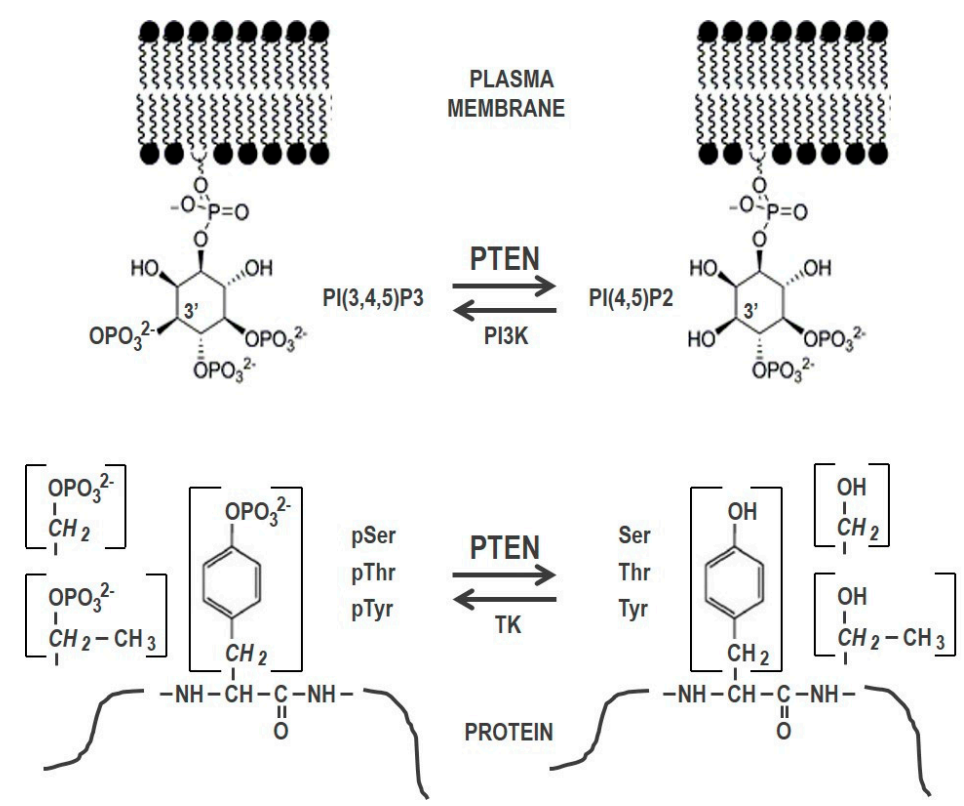

Figure 1. Schematic depiction of PTEN generic substrates. In the upper panel, dephosphorylation of $\mathrm{PI}(3,4,5) \mathrm{P} 3$ at the plasma membrane is shown. In the bottom panel, protein dephosphorylation is shown, with the side chain of Ser, Thr, or Tyr amino acids in brackets. PI3K, phosphatidylinositol-4, 5-bisphosphate 3-kinase; TK, tyrosine kinase.

Moreover, PTEN gene is mutated with relatively high frequency in the germline of PHTS (PTEN Hamartoma Tumor Syndrome) and Macrocephaly / Autism Syndrome patients [8-10]. A role for PTEN as a inositol 1,3,4,5,6-pentakisphosphate [I(1,3,4,5,6)P5] phosphatase has also been proposed, although it is not clear whether this activity is physiologically relevant [11-13] (Table 1). PTEN protein phosphatase activity has been reported towards a variety of membrane bound, cytoplasmic, and nuclear protein substrates, although in some cases it is uncertain whether these are bona fide PTEN direct substrates (Table 1). It has been proposed that the major physiologic effect of PTEN protein phosphatase activity is its autodephosphorylation at the C-terminal region [14,15]. This would restrain PTEN intramolecular interactions, regulating its subcellular location and modulating positively its lipid phosphatase activity [14,16-18]. Defined mutations at the PTEN active site have rendered PTEN variants with specific loss of lipid- or protein-phosphatase activity [19-21]. These PTEN variants are currently used as instrumental tools in the laboratory to delineate the catalytic requirements of the diverse PTEN biological activities. However, the differential physiologic regulation of PTEN lipidand protein-phosphatase activities is unknown, and the identification of inhibitors that only affect one of these activities, but not the other, is not documented.

Regulation of PTEN expression levels, protein conformation, and subcellular localization, is achieved by a variety of genetic, epigenetic, postranscriptional, and postranslational mechanisms affecting PTEN gene, mRNA, and protein [1,2,22]. Pathologic alterations of these mechanisms may cause a decrease in PTEN protein, or PTEN mislocalization, which associate with cancer predisposition $[23,24]$. In addition, PTEN catalysis is regulated in vivo by intracellular redox, a process which differentially affects to distinct groups of Cys-based PTPs [25-28]. In particular, the PTEN Cys124 catalytic residue at the active site is highly sensitive to oxidation and forms a disulfide bond with the Cys71 residue in the presence of reactive oxygen species (ROS), which permits reversible inactivation of the enzyme [29]. Several redox-effector proteins, including glutathione [30], peroxiredoxin 1 (Prdx1) [31], thioredoxin 1 (Trx1) [26,32], and glutaredoxin 5 (Grx5) [33] have been proposed to reactivate PTEN catalysis in cells by reducing its oxidized form. 
Table 1. Physiologic/potential PTEN substrates ${ }^{1}$.

\begin{tabular}{|c|c|c|}
\hline Substrate & Functional Outcome of Dephosphorylation & References \\
\hline \multicolumn{3}{|c|}{ Phosphatydilinositol/Inositol substrates (3' specificity) } \\
\hline $\mathrm{PI}(3,4,5) \mathrm{P} 3, \mathrm{PI}(3,4) \mathrm{P} 2^{2}$ & Inhibition of PI3K/AKT/mTOR pathway & {$[6,7,34]$} \\
\hline $\mathrm{I}(1,3,4,5,6) \mathrm{P} 5^{3}$ & Inhibition of cell proliferation & [11-13] \\
\hline \multicolumn{3}{|l|}{ Protein substrate 4} \\
\hline AKT (Thr) & AKT inactivation & [35] \\
\hline b-catenin (Tyr) & Maintenance of cell-cell adhesion & [36] \\
\hline Cofilin-1 (Ser) & Activation of actin depolymerization & {$[37]$} \\
\hline CREB (Ser) & CREB inactivation & [38] \\
\hline Drebrin (Ser) & Changes in neuronal actin dynamics & [39] \\
\hline EphR (Tyr) (C. elegans) & EphR inactivation & [40] \\
\hline FAK (Tyr) & Inhibition of directional cell migration & [41] \\
\hline FYN (Tyr) & FYN inactivation & [42] \\
\hline IR (Tyr) & IR inactivation & [43] \\
\hline IRF3 (Ser) & Inhibition of IRF3 nuclear import & [44] \\
\hline IRS1 (Tyr) & Inhibition of insulin and IGF signaling & [45] \\
\hline MCM2 (Ser) & Inhibition of replication fork progression & [46] \\
\hline PDGFR (Tyr) & PDGFR inactivation & [47] \\
\hline PTEN (Ser, Thr) & PTEN conformational opening and activation & {$[14,15,48]$} \\
\hline PTK6 (Tyr) & PTK6 inactivation & [49] \\
\hline p85b (Tyr, Thr) & AKT inactivation & [50] \\
\hline Plk1 (Thr) & Plk1 inactivation & [51] \\
\hline Rab7 (Tyr, Ser) & Promotion of late endosomal maturation & {$[52]$} \\
\hline SHC (Tyr) & Inhibition of random cell migration & [53] \\
\hline SRC (Tyr) & SRC inactivation & {$[54]$} \\
\hline 5-HT2cR & 5-HT2cR inactivation & [55] \\
\hline
\end{tabular}

${ }^{1}$ Updated from reference [1]; ${ }^{2} \mathrm{PI}(3,4,5) \mathrm{P} 3$ is the more physiologically relevant PTEN phosphatydilinositol substrate; ${ }^{3}$ Physiological dephosphorylation of $\mathrm{I}(1,3,4,5,6) \mathrm{P} 5$ by PTEN is under debate; ${ }^{4}$ Potential protein substrates (not validated as PTEN direct substrates in all cases). Dephosphorylation of Ser, Thr, or Tyr, is indicated in brackets. AKT, AKT/PKB kinase; CREB, cAMP response element-binding protein; EphR, Eph receptor; FAK, focal adhesion kinase; FYN, FYN kinase; IR, insulin receptor; IRF3, interferon-regulatory factor 3; IRS1, insulin receptor substrate-1; MCM2, maintenance complex component 2; PDGFR, platelet-derived growth factor receptor; Plk1, polo-like kinase 1; PTK6, protein tyrosine kinase 6; Rab7, Rab GTPase 7; SHC, Src homology 2 domain containing-adaptor protein; SRC, SRC kinase; 5-HT2cR, serotonin 5-HT2c receptor.

\section{Small Molecule PTEN Inhibitors}

The overall positive role of the PI3K/AKT/mTOR signaling pathway in cell growth and survival makes the rational for the therapeutic targeting of PTEN-deficient cancers with PI3K, AKT, or mTOR small molecule inhibitors [56]. Alternatively, reconstitution of PTEN expression or activity, when feasible, could also decrease PI3K-mediated oncogenic signaling, with potential therapeutic benefit in PTEN-deficient cancers [57,58]. On the other hand, in physiologic cell regeneration processes, or in conditions associated to neurodegeneration, tissue injury or ischemia, as well as in insulin resistance metabolic disorders, increased signaling through the PI3K/AKT/mTOR pathway is needed, making inhibition of PTEN catalysis a potential pharmacologic intervention (Figure 2) [59-61]. The potential side effects of inhibiting the catalytic activity of PTEN tumor suppressor are manifest. This prompts to methodologies (not addressed in this review) that specifically interfere with the distinct PTEN biological activities, without targeting directly PTEN catalytic active site, as suitable alternatives to PTEN catalysis inhibition.

Vanadium and peroxovanadium compounds are extensively used as general inhibitors of protein tyrosine phosphatases [62-64]. More in particular, bisperoxovanadium compounds, including $\mathrm{bpV}$ (phen) (bisperoxovanadium 1,10-phenantroline), $\mathrm{bpV}(\mathrm{pic})$ (bisperoxovanadium 5-hydroxipyridine), bpV(HOpic) (bisperoxovanadium 5-hydroxipyridine-2-carboxylic acid), bpV(pis) (bisperoxovanadium pyridin-2-squaramide), as well as the related vanadium complex VO-OHpic (hydroxyl(oxo)vanadium 3-hydroxypiridine-2-carboxylic acid) have been proposed as reversible and relatively specific small molecule PTEN inhibitors, with IC50 values in the nM range [65-68] 
(Table 2). PTEN inhibition by bpV(phen) is caused by the formation of Cys124-Cys71 oxidative disulfide-bridged PTEN species, which can be reverted by reducing agents, as it happens with the inhibition of PTEN by ROS [26,69]. In addition, a phenanthrenedione-related compound, SF1670 ( $N$-(9,10-dioxo-9,10-dihydrophenanthren-2-yl)pivalamide), is also currently being used experimentally at the low $\mu \mathrm{M}$ range as a relatively specific PTEN inhibitor [70,71] (Table 2), although the analysis of SF1670 to target selectively PTEN has not been fully addressed. Therapeutic use of these compounds is not only challenged by their potential negative influence in cancer prevention, but also for their likely additional selectivity towards other PTPs under physiologic conditions [72-75]. This makes necessary further deep investigation before the current PTEN inhibitors can be safely used in human therapy. Table 3 shows a list of diseases and conditions in which pharmacologic inhibition of PTEN by these small molecule inhibitors has been experimentally explored as a potential therapeutic approach.

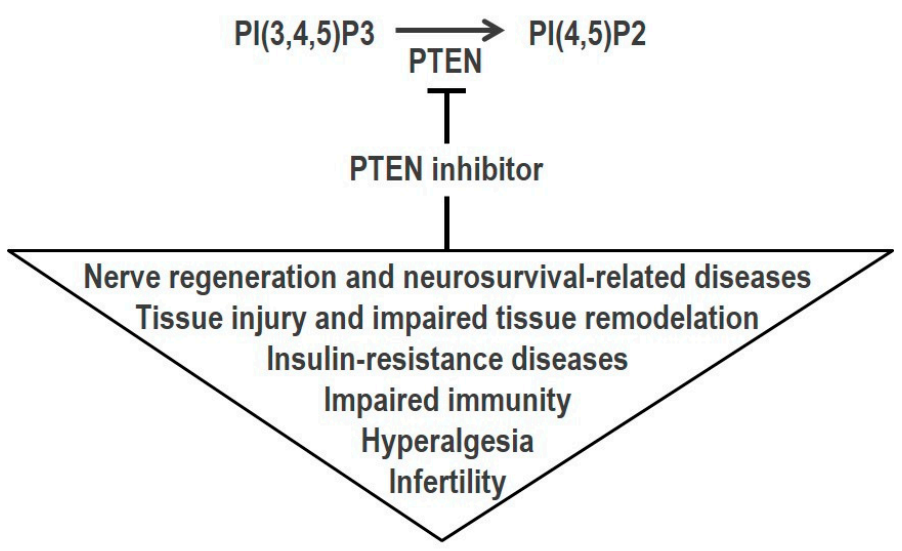

HUMAN DISEASES POTENTIALLY BENEFITED FROM PTEN INHIBITION

Figure 2. Significance of PTEN inhibition in human disease therapy. Human diseases which could benefit from PTEN pharmacologic inhibition are indicated (see text for a more comprehensive description). Note that the potential beneficial effect of PTEN inhibition has been related with PTEN PI $(3,4,5)$ P3 lipid phosphatase activity. Whether PTEN inhibition may be beneficial in some conditions in relation to PTEN protein phosphatase activity needs to be explored.

Table 2. PTEN inhibitors ${ }^{1}$.

\begin{tabular}{cccc}
\hline Inhibitor & Chemical Name & IC50 \\
\hline $\mathrm{bpV}(\mathrm{phen})$ & bisperoxovanadium 1,10-phenantroline \\
$\mathrm{bpV}(\mathrm{pic})$ & bisperoxovanadium 5-hydroxipyridine & \\
bpV(HOpic) & 5-hydroxipyridine-2-carboxylic acid
\end{tabular}


Table 2. Cont.

\begin{tabular}{|c|c|c|c|c|}
\hline Inhibitor & Chemical Name & IC50 & Chemical Structure & Reference \\
\hline $\mathrm{bpV}(\mathrm{pis})$ & $\begin{array}{l}\text { bisperoxovanadium } \\
\text { pyridin-2-squaramide }\end{array}$ & $39 \mathrm{nM}$ & & [68] \\
\hline VO-OHpic & $\begin{array}{l}\text { hydroxyl(oxo)vanadium } \\
\text { 3-hydroxypiridine-2-carboxylic acid }\end{array}$ & $35 \mathrm{nM}$ & & [66] \\
\hline SF1670 & $\begin{array}{c}N-(9,10-\text { dioxo-9, } 10 \text {-dihydrophenanthren } \\
\text {-2-yl) pivalamide }\end{array}$ & $2 \mu \mathrm{M}$ & & [70] \\
\hline
\end{tabular}

${ }^{1}$ Small molecule compounds currently used as direct inhibitors of PTEN catalysis are indicated.

Table 3. Selected studies using small molecule PTEN inhibitors with potential therapeutic application.

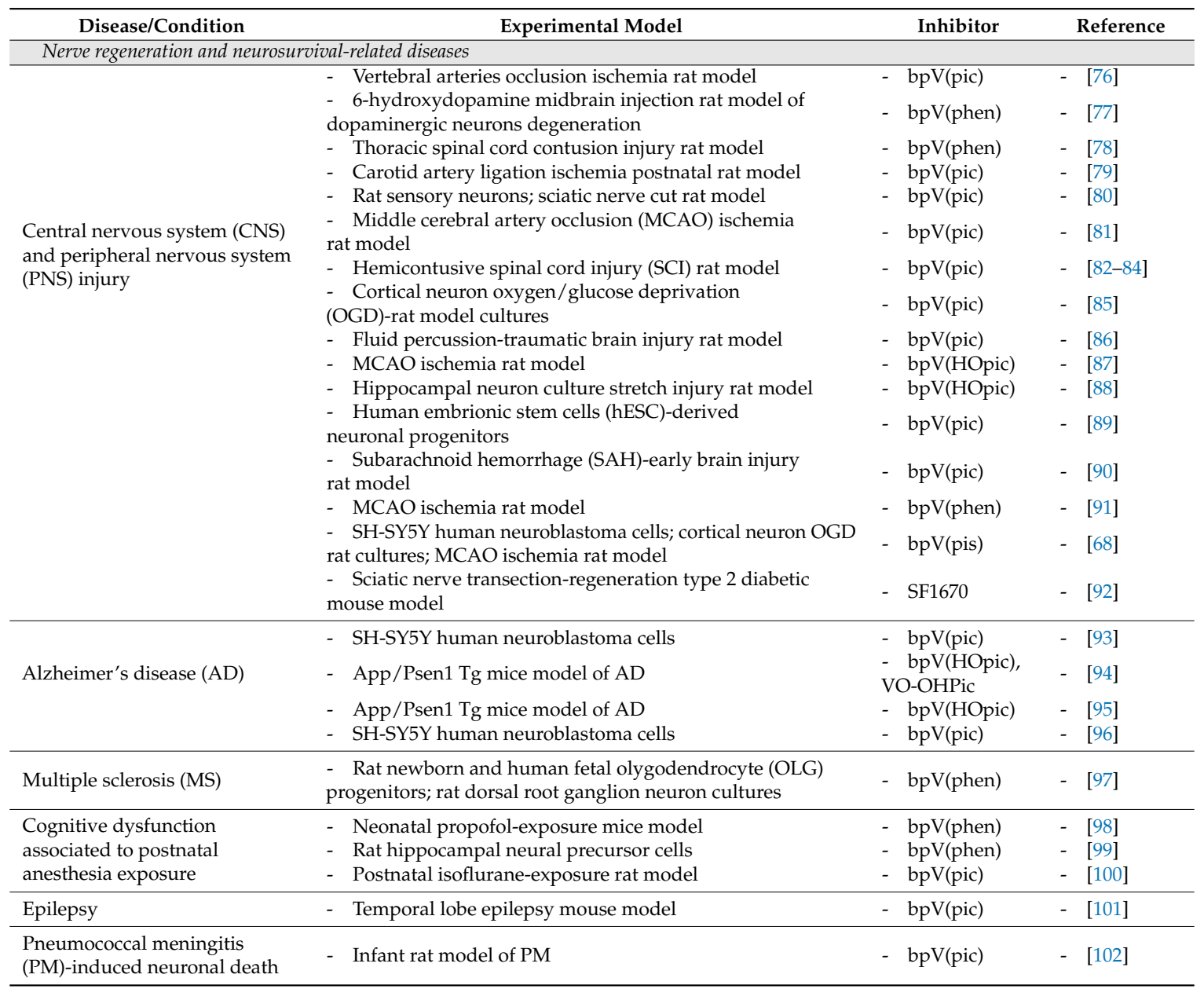


Table 3. Cont.

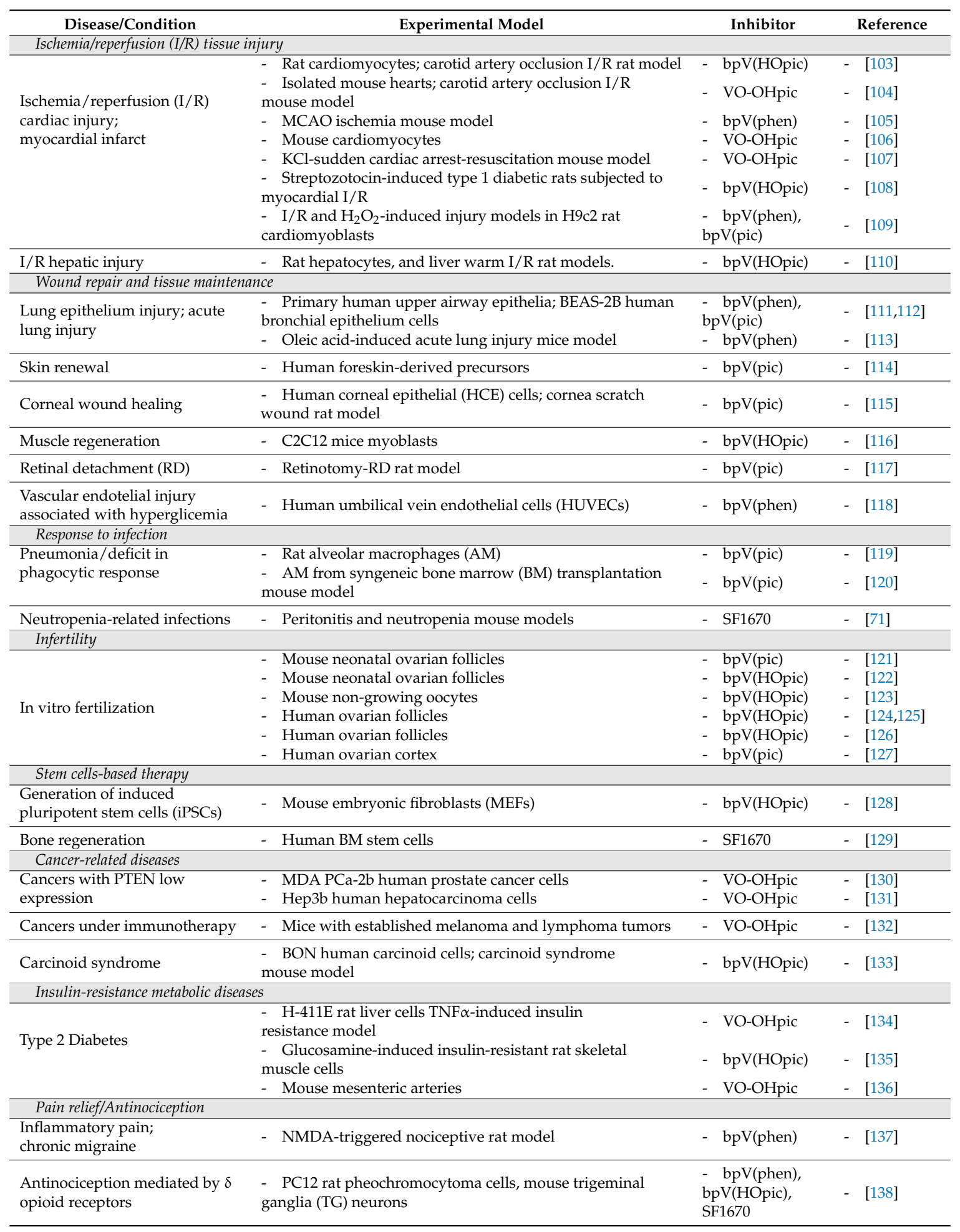

\section{PTEN Inhibition by Small Molecules in Human Disease Therapy}

\subsection{Nerve Regeneration and Neurosurvival-Related Diseases}

Downregulation of signaling through the axis PI3K/AKT/GSK-3 $\beta$ /mTOR by neuronal PTEN restrains axon outgrowth and nerve regeneration in peripheral and central nervous systems, both during embryonic development and after neuronal injury or ischemia. In addition, PTEN plays 
an important role in limiting the synaptic function in the signaling through NMDA and AMPA receptors. This makes inhibition of PTEN a feasible molecular approach to revert neurological damage under pathological circumstances [139-144].

The stimulation of nerve growth and regeneration after physical, ischemic, or diabetic damage to brain or peripheral neurons constitute one of the more feasible PTEN inhibition-based therapies. In line with the reports by Park et al. on the promotion of axon regeneration after optic nerve injury in PTEN retinal ganglion cells conditional knockout mice [145], and by Liu et al. on the positive effect on axon regrowth following spinal cord injury in corticospinal neurons PTEN-deleted mice [146], many animal studies support the AKT/GSK-3 $\beta / \mathrm{mTOR}$-dependent negative role of PTEN in nerve growth and regeneration [147-156]. Accordingly, pre-injury and post-injury treatment with PTEN-inhibiting bpV compounds has shown to be beneficial in several rat models of brain-, spinal cord-, and sensory neurons-traumatic injury (Table 3 , and references therein). Combination therapy using bpV(pic) and Schwann cell transplantation further improved motor neuron repair after cervical contusive spinal cord injury in rats [83]. In line with drug-combination treatments, GSK-3 $\beta$, a downstream effector in PTEN-mediated signaling, is also a pro-apoptotic enzyme that inhibits neuroprotection upon neuronal injury $[85,157]$. It would be interesting to test the potential additive effect in neuronal survival and regeneration of inhibiting pharmacologically both PTEN and GSK-3 $\beta$.

PTEN expression and subcellular compartmentation are altered in the brain from Alzheimer's disease (AD) patients [158-161], and the involvement of PTEN in regulating tau phosphorylation and amyloid $\beta(\mathrm{A} \beta)$ peptide-induced neurotoxicity in human cell lines and mouse primary neuron cultures has been documented $[93,95,161,162]$. In this context, a physical association between tau and PTEN in N1E115 human neuroblastoma cells has been described, which resulted in restraining of PTEN lipid phosphatase activity [163]. bpV(pic) treatment of SH-SY5Y human neuroblastoma cells resulted in inhibition of okadaic acid-induced tau phosphorylation [93], as well as in protection to $\mathrm{A} \beta$ (25-35)-induced toxicity [96]. In addition, VO-OH(pic) treatment of APP/Psen transgenic mice, a mouse model of AD, rescued synaptic function and mouse cognitive deficits, in parallel with protecting from $\mathrm{A} \beta$ (49)-induced NMDAR-dependent long term depression and synaptic toxicity events, a phenomena which was dependent on PTEN recruitment to synaptic spines through PTEN-PDZ interactions [94,164]. In line with a positive role for PTEN in facilitating AD-related neurodegeneration, APP/Psen transgenic mice were found to display increased PTEN expression in the hippocampus, and treatment with bpV(HOpic) decreased apoptosis of hippocampus neuronal cells [95].

Mice with conditional deletion of Pten gene in neurons, oligodendrocytes (OLGs), or glial cells display hypermyelination, which is accompanied, in some models, by progressive myelin sheath abnormalities and white matter degeneration [165-168]. Furthermore, OLG PTEN-deleted mice challenged with lysolecithin injection into the spinal cord white matter, a model of CNS demyelination, did not show improvement in myelin repair [167]. In contrast, it has been reported that combination of bpV(phen) and insulin-like growth factor-1 (IGF-1) promotes myelination in rat and human OLG progenitors cultures [97], suggesting a potential therapeutic application of bpV(phen) in multiple sclerosis (MS). Whether bpV compounds are effective pro-myelinating agents in in vivo models needs to be addressed. In this regard, cerebellar granule cells (GC) PTEN-deleted mice displayed an expanded population of OLG progenitors, with enhanced OLG differentiation and de novo myelination [169], whereas antigen presenting cells (APCs) PTEN-deleted mice displayed protection to inflammatory demyelinating experimental autoimmune encephalomyelitis (EAE) [170]. Further studies are necessary to delineate the physiologic role of PTEN in the different stages of myelination and the potential benefit of PTEN inhibition in myelination-related disorders therapy.

Long-term cognitive and learning dysfunctions are associated with repeated exposure of infants to anesthesia, in association with neurotoxicity and deficits in neurogenesis and neural precursor cells self-renewal [171]. In a neonatal propofol-exposure mice model, PTEN expression was increased while phospho-AKT decreased in dorsal hippocampus, and administration of 
$\mathrm{bpV}$ (phen) reverted the decrease in hippocampal long-term potentiation and long-term memory [98]. Similarly, bpV(pic) administration in a postnatal isoflurane-exposure rat model resulted in improvement in learning and memory performance, in parallel with the restoration of the PSD-95/NMDAR synaptic function and attenuation of tau phosphorylation [100].

It has been reported the neuroprotective effect of $\mathrm{bpV}(\mathrm{pic})$ in a hippocampal-excitotoxic mouse model of acquired temporal lobe epilepsy (TLE) triggered by intraperitoneal injection of kainic acid, in parallel with an increase in phospho-AKT levels. Interestingly, PTEN accumulated in the mitochondria from hippocampal cells following kainic acid treatment of mice, an event that was delayed in mice treated with $\mathrm{bpV}$ (pic) [101]. This could suggest a positive role for mitochondrial PTEN in mediating TLE-related neuronal excitoxicity. On the other hand, total or partial loss-of-function mutations at the PTEN gene are frequent in the germline of patients with Cowden disease, one of the major manifestations of PHTS, and several cases of patients with Cowden disease associated to epilepsy have been reported [172-176]. This suggests that impaired PTEN function may favor epilepsy episodes, in agreement with the notion of using inhibitors of the mTOR PTEN downstream effector as antiepileptic drugs [177]. Whether PTEN inhibition may be therapeutically beneficial in human epilepsy demands further investigation.

Finally, bpV(pic) also restored phospho-AKT levels and attenuated apoptosis in hippocampal developing neurons in an infant rat model of pneumococcal meningitis [102].

\subsection{Ischemia/Reperfusion Tissue Injury}

Ischemia/reperfusion (I/R)-associated diseases constitute one of the most frequent causes of death in humans, mainly due to the instrumental role of $I / R$ on myocardial infarct and stroke. Tissue damage is elicited by the lack of oxygen and nutrients supply during the ischemic period and it is exacerbated after tissue reoxygenation, which triggers a ROS-mediated damaging and proinflammatory response [178]. Since signaling through the PI3K/AKT/mTOR pathway is an important protection mechanism against I/R injury, especially in the case of ischemic conditioned cardiac tissue, PTEN inhibition has been proposed as a suitable therapeutic intervention in I/R cardiac damage [179]. In line with this, PTEN protein degradation and oxidative-inactivation were increased in perfused rat hearts during ischemia preconditioning, in parallel with augmented phospho-AKT levels and cardioprotection [180]. In addition, PTEN +/- mice display improved protection induced by ischemic preconditioining and attenuated inflammation and myocardial remodeling after myocardial infarction [181,182], whereas deletion of Pten gene in cardiomyocytes results in cardiac hypertrophy and cardiac contractility dysfunction, as well as in protection to pathological hypertrophy in response to pressure overload [183-185]. Thus, full inhibition of PTEN in muscle cardiac cells may be causative of pathology, although could be beneficial after acute episodes of cardiac damage. Interestingly, PTEN deletion in myeloid cells was protective for liver I/R injury by increasing the non-inflammatory M2 macrophage population [186].

The work of Keyes et al. testing the effect of bpV(HOpic) in rat cardiomyocytes subjected to I/R [103] was followed by additional studies using different PTEN inhibitors and I/R mechanical and chemical rat and mouse models (Table 3, and references therein). Overall, treatment with bisperoxovanadium and vanadium derivatives resulted in protection to $I / R$ cardiac injury and improvement of cardiac functions. Importantly, I/R hepatic injury was also attenuated by $\mathrm{bpV}(\mathrm{HOpic})$ administration in rat hepatocytes I/R models [110], whereas PTEN inhibition by $\mathrm{bpV}(\mathrm{HOpic})$ or $\mathrm{bpV}$ (pic) aggravated renal dysfunction and triggered tubular damage in acute I/R and cisplatin/induced kidney injury mouse models $[187,188]$. This illustrates how tissue-specificity may be relevant in the potential implementation of PTEN inhibitors in human disease therapy.

\subsection{Wound Repair and Tissue Maintenance}

Wound healing responses include polarized endothelial cell migration accompanied by cell survival and proliferation, which are positively regulated by the PI3K/AKT/mTOR pathway. 
Accordingly, PTEN activity has been associated with delayed wound healing in several human cell types and rodent models, including lung epithelial injury-, muscle regeneration-, skin healing-, or gastric mucosa integrity-models, among others [189-193]. Interestingly, opposite sensitivity responses to acute lung injury have been found in lung epithelial PTEN-deleted mice depending on the lung region affected [191,194]. This should be taken into consideration for the application of lung injury PTEN inhibition-based therapeutic interventions.

The beneficial effects of different bpV compounds on lung, vascular and corneal epithelium injury-, skin renewal-, muscle regeneration-, and retinal detachment-models have been reported (Table 3, and references therein). Remarkably, in vitro studies with epithelial human cells have revealed that enhanced cell migration accounts for the majority of wound repair upon PTEN inhibition with $\mathrm{bpV}$ (phen) [112]. Since PTEN protein phosphatase activity plays a major role in the regulation of cell migration [195], an attractive approach for wound healing and tissue repair therapies could be the use of protein phosphatase activity-specific PTEN inhibitors.

\subsection{Response to Infection}

A negative role for PTEN in host defense phagocytic functions, including decreasing chemotaxis, recruitment to inflamed sites, and Fc $\gamma$-R-mediated responses, has been evidenced using ex vivo macrophage cell models and myeloid cells PTEN-knockout mice [119,196-198]. This sustains the potential use of PTEN inhibitors to improve or restore the phagocytic immune response after bacterial infection, especially in cases of impaired innate immune response or immune system-depletion therapies. In this context, $\mathrm{bpV}$ (pic) treatment of rat alveolar macrophages (AM) was beneficial to restore the phagocytic response to sheep red blood cell challenging under conditions of prostaglandin E2-mediated Fc $\gamma$-R inhibition [119]. Similarly, AM from bone marrow transplanted mice with impaired lung host defense against Pseudomonas aeruginosa showed restored phagocytosis upon bpV(pic) treatment [120]. Finally, Li et al. has reported the favorable use of SF1670 compound to enhance the efficacy of granulocyte transfusion upon neutropenia-related infections, both in terms of granulocyte recruitment to inflamed sites and phagocytic functions [71].

\subsection{Infertility}

The work with oocyte PTEN-deleted mice indicates that PTEN is essential to limit the activation of primordial ovarian follicles, but not of growing developed follicles, and that lack of PTEN function may be causative of premature ovarian failure (POF) $[199,200]$. Also, ovarian granulosa cells PTEN-deleted mice displayed enhanced ovulation and fertility [201]. This suggests potential benefits for PTEN inhibition in in vitro fertility interventions. In fact, transient treatment of neonatal mouse ovarian follicles with $\mathrm{bpV}(\mathrm{pic})$ or $\mathrm{bpV}(\mathrm{HOpic})$ resulted in improved maturation of oocytes, which generated healthy and fertile progeny after in vitro fertilization and embryo transfer [121,122]. Short-term treatment with $\mathrm{bpV}$ (pic) of fresh or cryopreserved human ovarian tissue was also beneficial to enhance the in vitro activation of primordial follicles and the efficacy of fertility preservation [127]. Furthermore, treatment of human ovarian follicles from POF patients with a combination of bpV(HOpic) and 740 Y-P PI3K activator, followed by autotransplantation, in vitro fertilization, and embryo transfer, was positive for successful reproduction in some patients [124,125]. However, it has also been reported that human ovarian follicles in culture treated with $\mathrm{bpV}(\mathrm{pic})$ or $\mathrm{bpV}(\mathrm{HOpic})$ displayed limited growth and reduced survival [126,202]. In addition, deletion of PTEN in ovarian theca cells resulted in aberrant androgenesis and early fertility loss, reminiscent of human polycystic ovary syndrome [203]. Thus, transient low-dose inhibition of PTEN during in vitro manipulation of ovarian cells arises as a suitable approach to improve in vitro fertilization techniques.

\subsection{Stem Cells-Based Therapy}

PTEN plays a crucial and tissue-specific role in stem cell maintenance and self-renewal, with important manifestations in development and tumorigenesis [204,205]. PTEN-knockdown human 
embryonic stem cells (hESCs) display increased self-renewal, survival, and proliferation, as well as aberrant differentiation potential manifested as a bias toward neuroectoderm differentiation [206]. In mammalian spermatogonial stem cells, PTEN knockdown resulted in higher Nanog expression [207], and a role for PTEN in cell reprogramming of human and mouse fibroblasts has also been proposed based on the enhancement of generation of induced pluripotent stem cells (iPSCs) upon knockout or down-regulation of PTEN expression $[128,208]$. Furthermore, transient inhibition of PTEN by $\mathrm{bpV}(\mathrm{HOpic})$ in mouse embryonic fibroblasts (MEFs) enhanced the production of three-layer germline-competent iPSCs upon ectopic expression of OKSM or OKS factors, in association with accelerated cell proliferation during the early phase of reprogramming [128]. It would be necessary to test whether these observations can be extended to human fibroblasts. Finally, treatment of human bone marrow-derived stromal cells (hBMSC) with SF1670 increased osteogenic differentiation in vitro, in agreement with the findings that osteoblast PTEN-knockout mice displayed increased bone mineralization and improved healing of bone fracture $[209,210]$. This suggests a potential benefit for PTEN inhibition in conditions where bone mineralization and regeneration needs to be enhanced.

\subsection{Cancer-Related Diseases}

In spite of its role as a major tumor suppressor in many types of cancer, some studies have highlighted the possibility that PTEN pharmacologic inhibition may be an anticancer therapeutic approach under certain circumstances. It has been shown that in prostate PTEN-deleted mice, as well as in PTEN-deleted MEFs or PTEN-deficient human glioblastoma cells, a p53-dependent senescence program is triggered (PTEN-loss-induced cellular senescence, PICS) that restricts tumorigenic processes $[130,211,212]$. It has also been reported that, upon VO-OHpic treatment, cell senescence is induced and xenograft tumorigenic growth is decreased in Pten +/ - MEFs or in human prostate or hepatocarcinoma cancer cells expressing reduced levels of PTEN [130,131]. Of relevance, the cell viability inhibitory effect of VO-OHpic in Hep3b hepatocarcinoma cells in vitro was synergistic with the inhibitory effect of drugs targeting VEGFR, MEK, or PI3K/mTOR oncogenic kinases [131]. This opens the possibility that the combined treatment of PTEN inhibitors with currently used targeted therapies could be beneficial in PICS-competent cancers.

A role for PTEN in the suppression of the anticancer immune response has been proposed based on the findings that mice with PTEN deleted in regulatory T-cells (Tregs) are more prone to tumorigenesis and inflammation due to a deficient immunosuppressive T-cell activity in the tumor microenvironment. Furthermore, VO-OHpic treatment of mice with established melanoma or lymphoma tumors resulted in the induction of an inflammatory antitumor response [132], suggesting that pharmacological inhibitory targeting of PTEN could add benefits to anticancer immunotherapies. However, it has also been reported that PTEN deficiency in Tregs causes an autoimmune-lymphoproliferative and proinflammatory disease, as a result of the expansion of Thelper-cell populations [213,214]. In addition, PTEN deletion in tumor melanoma cells inhibited T-cell mediated anticancer responses, in line with the notion that PTEN expression in melanoma tumors correlates with higher immune surveillance responses [215]. Together, these observations indicate that a transient and cell-specific PTEN inhibition would be necessary to achieve benefits in the context of anticancer immunotherapies.

Finally, treatment of the BON human carcinoid cell line with VO-OHpic reduced serotonin secretion, which is symptomatic of carcinoid syndrome that occurs secondary to a fraction of carcinoid tumors [133]. Since reduced expression of PTEN in BON cells after stable transfection of PTEN-shRNA resulted in higher metastatic potential in nude mice [216], the potential therapeutic use of PTEN inhibitors to ameliorate carcinoid syndrome has important limitations. It should be tested whether acute but transient pharmacologic PTEN inhibition reduces morbidity associated to carcinoid syndrome without exacerbating carcinoid tumors. 


\subsection{Insulin-Resistance Metabolic Diseases}

PTEN PIP3-phosphatase activity counteracts insulin signaling, making PTEN inhibition a potential therapeutic approach for type 2 diabetes $[61,217,218]$. Although systemic long-term PTEN pharmacological inhibition is likely to be harmful, it is possible that a tissue-specific intervention or a partial inhibition of PTEN might be beneficial in type 2 diabetes treatment. For instance, skeletal muscle, pancreatic $\beta$-cells-, or adipose tissue-PTEN-knockout mice displayed protection to insulin resistance and type 2 diabetes, without malignant cell growth or cancer manifestations [219-222]. Likewise, diminishing systemically PTEN levels with antisense oligonucleotides reverted insulin resistance and hyperglycemia in diabetic mice [223]. PTEN-antisense treatment of C2C12 mouse myoblasts abolished TNF $\alpha$-induced insulin resistance, which was associated with increased PTEN mRNA and protein levels [224]. Furthermore, PTEN increased expression in TNF $\alpha$-treated H-411E rat liver cells was reverted by treatment with VO-OHpic [134]. Importantly, VO-OHpic treatment of mouse mesenteric arteries challenged with $\mathrm{TNF} \alpha$, or treatment of arteries from mice fed with high fat diet, prevented the induction of vascular insulin resistance [136]. These findings suggest that PTEN inhibitors could prevent insulin resistance upon pathological circumstances. Further mechanistic studies are required to understand the regulation of PTEN expression in insulin-responsive tissues by $\mathrm{TNF} \alpha$ and upon PTEN catalysis inhibition.

\subsection{Pain Relief/Antinociception}

A role for PTEN in regulating hyperalgesia and nociception has been proposed based on the observations that animals from rat and mice models of migraine displayed improved mechanical thresholds and less spinal trigeminal neuron activation upon PTEN knockdown, in association with diminished tyrosine phosphorylation of the of the NMDA receptor NR2B subunit $[225,226]$. Accordingly, the increased mechanical allodynia shown by rats injected with NMDA was attenuated upon co-injection with $\mathrm{bpV}$ (phen), with concomitant decrease in Src-mediated NR2B phosphorylation [137]. In addition, PTEN has been involved in the negative regulation in sensory neurons of surface expression of $\delta$ opioid analgesic receptors ( $\delta \mathrm{R})$. Treatment of PC12 rat pheochromocytoma cells or mouse trigeminal neurons with $\mathrm{bpV}(\mathrm{phen}), \mathrm{bpV}(\mathrm{HOpic})$, or SF1670 promoted the surface delivery of newly synthesized $\delta R$, which resulted in increased antihyperalgesic efficacy of $\delta R$ upon agonist stimulation [138]. These findings suggest that pharmacological PTEN inhibition could be beneficial in attenuation of chronic pain processes or in analgesic interventions using $\delta \mathrm{R}$ agonists. However, in a rat neuropathic model of chronic constriction injury, downregulation of spinal cord PTEN was associated with nociception [227], suggesting that PTEN activity could also support antinociceptive functions. Further work is required to ascertain the role of PTEN in pain modulation under physiological and pathological conditions.

\section{Concluding Remarks}

Important efforts have been made to develop specific and biologically active small molecule PTEN inhibitors, and to validate them as suitable experimental and clinical tools. This has provided compounds targeting PTEN that are widely used in research, as well as the proof-of-concept that PTEN pharmacologic inhibition could be beneficial for human welfare in specific diseases or conditions. Although currently available PTEN inhibitors are commonly used in many studies as specific and potent PTEN inhibitors, evidence exists that most of these compounds target, at least, several PTPs, and that their potency is dependent on the redox experimental conditions [75]. This makes convenient the refinement in the obtaining and characterization of PTEN inhibitors, both in terms of potency and target selectivity. Examples exist that some bpV compounds frequently used as PTEN inhibitors may cause beneficial pathology-related effects with independence of PTEN inhibition, but likely dependent on inhibition of another PTP. For instance, injection of $\mathrm{bpV}(\mathrm{phen})$ in a murine model of allergic asthma resulted in decreased allergic and lung inflammatory responses [228], although a plethora of in vitro 
and in vivo studies support the notion that PTEN activity mitigates asthmatic features [229-233]. Promiscuous specificity does not necessarily accompany bad therapeutic outcomes for a given inhibitory compound, as illustrated with the current therapeutic use in clinical oncology of small molecules inhibiting several tyrosine kinase targets. As far as toxicity and side effects are limited, it is possible that multiple targeting helps the favorable therapeutic outcome of some current PTEN inhibitors. Thus, it has been proposed the added potential benefit to confer neuroprotection of the PTEN-partially selective bpV(pis) inhibitor by targeting both PTEN and the ERK1/2 MAPK pathway [68].

Regarding the use of current PTEN inhibitors in research, some aspects should be taken into consideration to endorse the assumption that the observed experimental effects of the compounds are, in fact, due to PTEN inhibition. These include, among others, dose-response analysis using more than one inhibitory compound; the analysis of pAKT content as an indirect readout of PTEN inhibition; the comparative analysis of both PTEN-positive and PTEN-negative cells; and the comparative analysis of the compound with PTEN-knockdown or PTEN dominant-negative strategies, if feasible.

Most of the pathologic conditions in which PTEN inhibition is proposed as a potential therapeutic approach rely on the direct negative control by PTEN PIP3-phosphatase activity on the signaling through the PI3K/AKT/mTOR pathway (Figure 2). However, evidence exists on the importance of PTEN protein-phosphatase activity, as well as non-catalytic PTEN activities, on physiologic and pathologic processes $[195,234]$. Whether selective inhibition by small molecules of PTEN lipid- or protein-phosphatase activity is achievable needs to be explored. In addition, since PTEN catalytic activity is involved in feedback loops that regulate PTEN expression, it would be interesting to test the effects of current PTEN inhibitors in non-catalytic PTEN functions, such as those exerted in the cell nucleus.

The current knowledge of the outcomes of PTEN pharmacologic inhibition discloses a wide scenario of possibilities for therapeutic intervention. In summary, acute local treatment with suboptimal doses of PTEN inhibitors, rendering tissue- or organ-specific tuned PTEN inactivation at well-defined frame times, could circumvent undesired side effects of chronic or total PTEN inactivation, and set the conditions for the beneficial use of PTEN inhibition in human disease therapy.

Acknowledgments: The work in R.P. laboratory is funded by grants SAF2016-79847-R from Ministerio de Economía y Competitividad (Spain and Fondo Europeo de Desarrollo Regional); 2013111011 from Gobierno Vasco, Departamento de Sanidad (Basque Country, Spain); and BIO13/CI/001/BC from BIOEF (EITB maratoia; Basque Country, Spain). R.P. is supported by IKERBASQUE, Basque Foundation for Science (Basque Country, Spain).

Conflicts of Interest: The author declares no conflict of interest.

\section{References}

1. Pulido, R. PTEN: A yin-yang master regulator protein in health and disease. Methods 2015, 77-78, 3-10. [CrossRef] [PubMed]

2. Worby, C.A.; Dixon, J.E. PTEN. Annu. Rev. Biochem. 2014, 83, 641-669. [CrossRef] [PubMed]

3. Malaney, P.; Uversky, V.N.; Dave, V. PTEN proteoforms in biology and disease. Cell. Mol. Life Sci. CMLS 2017, 74, 2783-2794. [CrossRef] [PubMed]

4. Lee, J.O.; Yang, H.; Georgescu, M.M.; Di Cristofano, A.; Maehama, T.; Shi, Y.; Dixon, J.E.; Pandolfi, P.; Pavletich, N.P. Crystal structure of the PTEN tumor suppressor: Implications for its phosphoinositide phosphatase activity and membrane association. Cell 1999, 99, 323-334. [CrossRef]

5. Maehama, T.; Dixon, J.E. PTEN: A tumour suppressor that functions as a phospholipid phosphatase. Trends Cell Biol. 1999, 9, 125-128. [CrossRef]

6. Malek, M.; Kielkowska, A.; Chessa, T.; Anderson, K.E.; Barneda, D.; Pir, P.; Nakanishi, H.; Eguchi, S.; Koizumi, A.; Sasaki, J.; et al. PTEN Regulates PI(3,4)P2 Signaling Downstream of Class I PI3K. Mol. Cell 2017, 68, 566-580. [CrossRef] [PubMed] 
7. Stambolic, V.; Suzuki, A.; de la Pompa, J.L.; Brothers, G.M.; Mirtsos, C.; Sasaki, T.; Ruland, J.; Penninger, J.M.; Siderovski, D.P.; Mak, T.W. Negative regulation of PKB/Akt-dependent cell survival by the tumor suppressor PTEN. Cell 1998, 95, 29-39. [CrossRef]

8. Hobert, J.A.; Eng, C. PTEN hamartoma tumor syndrome: An overview. Genet. Med. 2009, 11, 687-694. [CrossRef] [PubMed]

9. Tilot, A.K.; Frazier, T.W., II; Eng, C. Balancing Proliferation and Connectivity in PTEN-associated Autism Spectrum Disorder. Neurotherapeutics 2015, 12, 609-619. [CrossRef] [PubMed]

10. Zhou, J.; Parada, L.F. PTEN signaling in autism spectrum disorders. Curr. Opin. Neurobiol. 2012, $22,873-879$. [CrossRef] [PubMed]

11. Caffrey, J.J.; Darden, T.; Wenk, M.R.; Shears, S.B. Expanding coincident signaling by PTEN through its inositol 1,3,4,5,6-pentakisphosphate 3-phosphatase activity. FEBS Lett. 2001, 499, 6-10. [CrossRef]

12. Deleu, S.; Choi, K.; Pesesse, X.; Cho, J.; Sulis, M.L.; Parsons, R.; Shears, S.B. Physiological levels of PTEN control the size of the cellular Ins(1,3,4,5,6)P5 pool. Cell. Signal. 2006, 18, 488-498. [CrossRef] [PubMed]

13. Orchiston, E.A.; Bennett, D.; Leslie, N.R.; Clarke, R.G.; Winward, L.; Downes, C.P.; Safrany, S.T. PTEN $\mathrm{M}-\mathrm{CBR} 3$, a versatile and selective regulator of inositol 1,3,4,5,6-pentakisphosphate (Ins $(1,3,4,5,6) \mathrm{P} 5)$. Evidence for Ins $(1,3,4,5,6) \mathrm{P} 5$ as a proliferative signal. J. Biol. Chem. 2004, 279, 1116-1122. [CrossRef] [PubMed]

14. Tibarewal, P.; Zilidis, G.; Spinelli, L.; Schurch, N.; Maccario, H.; Gray, A.; Perera, N.M.; Davidson, L.; Barton, G.J.; Leslie, N.R. PTEN protein phosphatase activity correlates with control of gene expression and invasion, a tumor-suppressing phenotype, but not with AKT activity. Sci. Signal. 2012, 5, ra18. [CrossRef] [PubMed]

15. Zhang, X.C.; Piccini, A.; Myers, M.P.; van Aelst, L.; Tonks, N.K. Functional analysis of the protein phosphatase activity of PTEN. Biochem. J. 2012, 444, 457-464. [CrossRef] [PubMed]

16. Andrés-Pons, A.; Gil, A.; Oliver, M.D.; Sotelo, N.S.; Pulido, R. Cytoplasmic p27Kip1 counteracts the pro-apoptotic function of the open conformation of PTEN by retention and destabilization of PTEN outside of the nucleus. Cell. Signal. 2012, 24, 577-587. [CrossRef] [PubMed]

17. Rahdar, M.; Inoue, T.; Meyer, T.; Zhang, J.; Vazquez, F.; Devreotes, P.N. A phosphorylation-dependent intramolecular interaction regulates the membrane association and activity of the tumor suppressor PTEN. Proc. Natl. Acad. Sci. USA 2009, 106, 480-485. [CrossRef] [PubMed]

18. Vazquez, F.; Grossman, S.R.; Takahashi, Y.; Rokas, M.V.; Nakamura, N.; Sellers, W.R. Phosphorylation of the PTEN tail acts as an inhibitory switch by preventing its recruitment into a protein complex. J. Biol. Chem. 2001, 276, 48627-48630. [CrossRef] [PubMed]

19. Davidson, L.; Maccario, H.; Perera, N.M.; Yang, X.; Spinelli, L.; Tibarewal, P.; Glancy, B.; Gray, A.; Weijer, C.J.; Downes, C.P.; et al. Suppression of cellular proliferation and invasion by the concerted lipid and protein phosphatase activities of PTEN. Oncogene 2010, 29, 687-697. [CrossRef] [PubMed]

20. Luna, S.; Mingo, J.; Aurtenetxe, O.; Blanco, L.; Amo, L.; Schepens, J.; Hendriks, W.J.; Pulido, R. Tailor-Made Protein Tyrosine Phosphatases: In Vitro Site-Directed Mutagenesis of PTEN and PTPRZ-B. Methods Mol. Biol. 2016, 1447, 79-93. [PubMed]

21. Myers, M.P.; Pass, I.; Batty, I.H.; Van der Kaay, J.; Stolarov, J.P.; Hemmings, B.A.; Wigler, M.H.; Downes, C.P.; Tonks, N.K. The lipid phosphatase activity of PTEN is critical for its tumor supressor function. Proc. Natl. Acad. Sci. USA 1998, 95, 13513-13518. [CrossRef] [PubMed]

22. Hopkins, B.D.; Hodakoski, C.; Barrows, D.; Mense, S.M.; Parsons, R.E. PTEN function: The long and the short of it. Trends Biochem. Sci. 2014, 39, 183-190. [CrossRef] [PubMed]

23. Alimonti, A.; Carracedo, A.; Clohessy, J.G.; Trotman, L.C.; Nardella, C.; Egia, A.; Salmena, L.; Sampieri, K.; Haveman, W.J.; Brogi, E.; et al. Subtle variations in Pten dose determine cancer susceptibility. Nat. Genet. 2010, 42, 454-458. [CrossRef] [PubMed]

24. Ngeow, J.; He, X.; Mester, J.L.; Lei, J.; Romigh, T.; Orloff, M.S.; Milas, M.; Eng, C. Utility of PTEN protein dosage in predicting for underlying germline PTEN mutations among patients presenting with thyroid cancer and Cowden-like phenotypes. J. Clin. Endocrinol. Metab. 2012, 97, E2320-E2327. [CrossRef] [PubMed]

25. Kwon, J.; Lee, S.R.; Yang, K.S.; Ahn, Y.; Kim, Y.J.; Stadtman, E.R.; Rhee, S.G. Reversible oxidation and inactivation of the tumor suppressor PTEN in cells stimulated with peptide growth factors. Proc. Natl. Acad. Sci. USA 2004, 101, 16419-16424. [CrossRef] [PubMed]

26. Lee, S.R.; Yang, K.S.; Kwon, J.; Lee, C.; Jeong, W.; Rhee, S.G. Reversible inactivation of the tumor suppressor PTEN by $\mathrm{H}_{2} \mathrm{O}_{2}$. J. Biol. Chem. 2002, 277, 20336-20342. [CrossRef] [PubMed] 
27. Leslie, N.R.; Bennett, D.; Lindsay, Y.E.; Stewart, H.; Gray, A.; Downes, C.P. Redox regulation of PI 3-kinase signalling via inactivation of PTEN. EMBO J. 2003, 22, 5501-5510. [CrossRef] [PubMed]

28. Ross, S.H.; Lindsay, Y.; Safrany, S.T.; Lorenzo, O.; Villa, F.; Toth, R.; Clague, M.J.; Downes, C.P.; Leslie, N.R. Differential redox regulation within the PTP superfamily. Cell. Signal. 2007, 19, 1521-1530. [CrossRef] [PubMed]

29. Cho, S.H.; Lee, C.H.; Ahn, Y.; Kim, H.; Kim, H.; Ahn, C.Y.; Yang, K.S.; Lee, S.R. Redox regulation of PTEN and protein tyrosine phosphatases in $\mathrm{H}_{2} \mathrm{O}_{2}$ mediated cell signaling. FEBS Lett. 2004, 560, 7-13. [CrossRef]

30. Kim, Y.; Song, Y.B.; Kim, T.Y.; Kim, I.; Han, S.J.; Ahn, Y.; Cho, S.H.; Choi, C.Y.; Chay, K.O.; Yang, S.Y.; et al. Redox regulation of the tumor suppressor PTEN by glutathione. FEBS Lett. 2010, 584, 3550-3556. [CrossRef] [PubMed]

31. Cao, J.; Schulte, J.; Knight, A.; Leslie, N.R.; Zagozdzon, A.; Bronson, R.; Manevich, Y.; Beeson, C.; Neumann, C.A. Prdx1 inhibits tumorigenesis via regulating PTEN/AKT activity. EMBO J. 2009, 28, 1505-1517. [CrossRef] [PubMed]

32. Schwertassek, U.; Haque, A.; Krishnan, N.; Greiner, R.; Weingarten, L.; Dick, T.P.; Tonks, N.K. Reactivation of oxidized PTP1B and PTEN by thioredoxin 1. FEBS J. 2014, 281, 3545-3558. [CrossRef] [PubMed]

33. Kim, Y.; Chay, K.O.; Kim, I.; Song, Y.B.; Kim, T.Y.; Han, S.J.; Ahn, Y.; Cho, S.H.; Hoe, K.L.; Ahn, B.W.; et al. Redox regulation of the tumor suppressor PTEN by glutaredoxin 5 and Ycp4. Biochem. Biophys. Res. Commun. 2011, 407, 175-180. [CrossRef] [PubMed]

34. Maehama, T.; Dixon, J.E. The tumor suppressor, PTEN/MMAC1, dephosphorylates the lipid second messenger, phosphatidylinositol 3,4,5-trisphosphate. J. Biol. Chem. 1998, 273, 13375-13378. [CrossRef] [PubMed]

35. Phadngam, S.; Castiglioni, A.; Ferraresi, A.; Morani, F.; Follo, C.; Isidoro, C. PTEN dephosphorylates AKT to prevent the expression of GLUT1 on plasmamembrane and to limit glucose consumption in cancer cells. Oncotarget 2016, 7, 84999-85020. [CrossRef] [PubMed]

36. Vogelmann, R.; Nguyen-Tat, M.D.; Giehl, K.; Adler, G.; Wedlich, D.; Menke, A. TGFbeta-induced downregulation of E-cadherin-based cell-cell adhesion depends on PI3-kinase and PTEN. J. Cell Sci. 2005, 118, 4901-4912. [CrossRef] [PubMed]

37. Serezani, C.H.; Kane, S.; Medeiros, A.I.; Cornett, A.M.; Kim, S.H.; Marques, M.M.; Lee, S.P.; Lewis, C.; Bourdonnay, E.; Ballinger, M.N.; et al. PTEN directly activates the actin depolymerization factor cofilin-1 during PGE2-mediated inhibition of phagocytosis of fungi. Sci. Signal. 2012, 5, ra12. [CrossRef] [PubMed]

38. Gu, T.; Zhang, Z.; Wang, J.; Guo, J.; Shen, W.H.; Yin, Y. CREB is a novel nuclear target of PTEN phosphatase. Cancer Res. 2011, 71, 2821-2825. [CrossRef] [PubMed]

39. Kreis, P.; Hendricusdottir, R.; Kay, L.; Papageorgiou, I.E.; van Diepen, M.; Mack, T.; Ryves, J.; Harwood, A.; Leslie, N.R.; Kann, O.; et al. Phosphorylation of the actin binding protein Drebrin at 6647 is regulated by neuronal activity and PTEN. PLoS ONE 2013, 8, e71957. [CrossRef] [PubMed]

40. Brisbin, S.; Liu, J.; Boudreau, J.; Peng, J.; Evangelista, M.; Chin-Sang, I. A role for C. elegans Eph RTK signaling in PTEN regulation. Dev. Cell 2009, 17, 459-469. [CrossRef] [PubMed]

41. Tamura, M.; Gu, J.; Matsumoto, K.; Aota, S.; Parsons, R.; Yamada, K.M. Inhibition of cell migration, spreading, and focal adhesions by tumor suppressor PTEN. Science 1998, 280, 1614-1617. [CrossRef] [PubMed]

42. Dey, N.; Crosswell, H.E.; De, P.; Parsons, R.; Peng, Q.; Su, J.D.; Durden, D.L. The protein phosphatase activity of PTEN regulates SRC family kinases and controls glioma migration. Cancer Res. 2008, 68, 1862-1871. [CrossRef] [PubMed]

43. Liu, J.; Visser-Grieve, S.; Boudreau, J.; Yeung, B.; Lo, S.; Chamberlain, G.; Yu, F.; Sun, T.; Papanicolaou, T.; Lam, A.; et al. Insulin activates the insulin receptor to downregulate the PTEN tumour suppressor. Oncogene 2014, 33, 3878-3885. [CrossRef] [PubMed]

44. Li, S.; Zhu, M.; Pan, R.; Fang, T.; Cao, Y.Y.; Chen, S.; Zhao, X.; Lei, C.Q.; Guo, L.; Chen, Y.; et al. The tumor suppressor PTEN has a critical role in antiviral innate immunity. Nat. Immunol. 2016, 17, 241-249. [CrossRef] [PubMed]

45. Shi, Y.; Wang, J.; Chandarlapaty, S.; Cross, J.; Thompson, C.; Rosen, N.; Jiang, X. PTEN is a protein tyrosine phosphatase for IRS1. Nat. Struct. Mol. Biol. 2014, 21, 522-527. [CrossRef] [PubMed]

46. Feng, J.; Liang, J.; Li, J.; Li, Y.; Liang, H.; Zhao, X.; McNutt, M.A.; Yin, Y. PTEN Controls the DNA Replication Process through MCM2 in Response to Replicative Stress. Cell Rep. 2015, 13, 1295-1303. [CrossRef] [PubMed] 
47. Mahimainathan, L.; Choudhury, G.G. Inactivation of platelet-derived growth factor receptor by the tumor suppressor PTEN provides a novel mechanism of action of the phosphatase. J. Biol. Chem. 2004, 279, 15258-15268. [CrossRef] [PubMed]

48. Raftopoulou, M.; Etienne-Manneville, S.; Self, A.; Nicholls, S.; Hall, A. Regulation of cell migration by the C2 domain of the tumor suppressor PTEN. Science 2004, 303, 1179-1181. [CrossRef] [PubMed]

49. Wozniak, D.J.; Kajdacsy-Balla, A.; Macias, V.; Ball-Kell, S.; Zenner, M.L.; Bie, W.; Tyner, A.L. PTEN is a protein phosphatase that targets active PTK6 and inhibits PTK6 oncogenic signaling in prostate cancer. Nat. Commun. 2017, 8, 1508. [CrossRef] [PubMed]

50. He, J.; de la Monte, S.; Wands, J.R. The p85beta regulatory subunit of PI3K serves as a substrate for PTEN protein phosphatase activity during insulin mediated signaling. Biochem. Biophys. Res. Commun. 2010, 397, 513-519. [CrossRef] [PubMed]

51. Zhang, Z.; Hou, S.Q.; He, J.; Gu, T.; Yin, Y.; Shen, W.H. PTEN regulates PLK1 and controls chromosomal stability during cell division. Cell Cycle 2016, 15, 2476-2485. [CrossRef] [PubMed]

52. Shinde, S.R.; Maddika, S. PTEN modulates EGFR late endocytic trafficking and degradation by dephosphorylating Rab7. Nat. Commun. 2016, 7, 10689. [CrossRef] [PubMed]

53. Gu, J.; Tamura, M.; Pankov, R.; Danen, E.H.; Takino, T.; Matsumoto, K.; Yamada, K.M. Shc and FAK differentially regulate cell motility and directionality modulated by PTEN. J. Cell Biol. 1999, 146, 389-403. [CrossRef] [PubMed]

54. Zhang, S.; Huang, W.C.; Li, P.; Guo, H.; Poh, S.B.; Brady, S.W.; Xiong, Y.; Tseng, L.M.; Li, S.H.; Ding, Z.; et al. Combating trastuzumab resistance by targeting SRC, a common node downstream of multiple resistance pathways. Nat. Med. 2011, 17, 461-469. [CrossRef] [PubMed]

55. Ji, S.P.; Zhang, Y.; Van Cleemput, J.; Jiang, W.; Liao, M.; Li, L.; Wan, Q.; Backstrom, J.R.; Zhang, X. Disruption of PTEN coupling with 5-HT2C receptors suppresses behavioral responses induced by drugs of abuse. Nat. Med. 2006, 12, 324-329. [CrossRef] [PubMed]

56. Dillon, L.M.; Miller, T.W. Therapeutic targeting of cancers with loss of PTEN function. Curr. Drug Targets 2014, 15, 65-79. [CrossRef] [PubMed]

57. Boosani, C.S.; Agrawal, D.K. PTEN modulators: A patent review. Expert Opin. Ther. Pat. 2013, 23, 569-580. [CrossRef] [PubMed]

58. Kim, D.H.; Suh, J.; Surh, Y.J.; Na, H.K. Regulation of the tumor suppressor PTEN by natural anticancer compounds. Ann. N. Y. Acad. Sci. 2017, 1401, 136-149. [CrossRef] [PubMed]

59. Mak, L.H.; Woscholski, R. Targeting PTEN using small molecule inhibitors. Methods 2015, 77-78, 63-68. [CrossRef] [PubMed]

60. McLoughlin, N.M.; Mueller, C.; Grossmann, T.N. The Therapeutic Potential of PTEN Modulation: Targeting Strategies from Gene to Protein. Cell Chem. Biol. 2017. [CrossRef] [PubMed]

61. Rosivatz, E. Inhibiting PTEN. Biochem. Soc. Trans. 2007, 35, 257-259. [CrossRef] [PubMed]

62. Gordon, J.A. Use of vanadate as protein-phosphotyrosine phosphatase inhibitor. Methods Enzymol. 1991, 201, 477-482. [PubMed]

63. Huyer, G.; Liu, S.; Kelly, J.; Moffat, J.; Payette, P.; Kennedy, B.; Tsaprailis, G.; Gresser, M.J.; Ramachandran, C. Mechanism of inhibition of protein-tyrosine phosphatases by vanadate and pervanadate. J. Biol. Chem. 1997, 272, 843-851. [CrossRef] [PubMed]

64. Posner, B.I.; Faure, R.; Burgess, J.W.; Bevan, A.P.; Lachance, D.; Zhang-Sun, G.; Fantus, I.G.; Ng, J.B.; Hall, D.A.; Lum, B.S.; et al. Peroxovanadium compounds. A new class of potent phosphotyrosine phosphatase inhibitors which are insulin mimetics. J. Biol. Chem. 1994, 269, 4596-4604. [PubMed]

65. Mak, L.H.; Vilar, R.; Woscholski, R. Characterisation of the PTEN inhibitor VO-OHpic. J. Chem. Biol. 2010, 3, 157-163. [CrossRef] [PubMed]

66. Rosivatz, E.; Matthews, J.G.; McDonald, N.Q.; Mulet, X.; Ho, K.K.; Lossi, N.; Schmid, A.C.; Mirabelli, M.; Pomeranz, K.M.; Erneux, C.; et al. A small molecule inhibitor for phosphatase and tensin homologue deleted on chromosome 10 (PTEN). ACS Chem. Biol. 2006, 1, 780-790. [CrossRef] [PubMed]

67. Schmid, A.C.; Byrne, R.D.; Vilar, R.; Woscholski, R. Bisperoxovanadium compounds are potent PTEN inhibitors. FEBS Lett. 2004, 566, 35-38. [CrossRef] [PubMed]

68. Zhang, Z.F.; Chen, J.; Han, X.; Zhang, Y.; Liao, H.B.; Lei, R.X.; Zhuang, Y.; Wang, Z.F.; Li, Z.; Chen, J.C.; et al. Bisperoxovandium (pyridin-2-squaramide) targets both PTEN and ERK1/2 to confer neuroprotection. Br. J. Pharmacol. 2017, 174, 641-656. [CrossRef] [PubMed] 
69. Lee, C.U.; Hahne, G.; Hanske, J.; Bange, T.; Bier, D.; Rademacher, C.; Hennig, S.; Grossmann, T.N. Redox Modulation of PTEN Phosphatase Activity by Hydrogen Peroxide and Bisperoxidovanadium Complexes. Angew. Chem. Int. Ed. Engl. 2015, 54, 13796-13800. [CrossRef] [PubMed]

70. Garlich, J.R.; Durden, D.L.; Georgiadis, T.M.; Su, J.; Peng, X.; Smith, T.C. PTEN Inhibitors. Patent EP1755574 A2, 28 February 2007.

71. Li, Y.; Prasad, A.; Jia, Y.; Roy, S.G.; Loison, F.; Mondal, S.; Kocjan, P.; Silberstein, L.E.; Ding, S.; Luo, H.R. Pretreatment with phosphatase and tensin homolog deleted on chromosome 10 (PTEN) inhibitor SF1670 augments the efficacy of granulocyte transfusion in a clinically relevant mouse model. Blood 2011, 117, 6702-6713. [CrossRef] [PubMed]

72. Ajeawung, N.F.; Faure, R.; Jones, C.; Kamnasaran, D. Preclinical evaluation of dipotassium bisperoxo (picolinato) oxovanadate V for the treatment of pediatric low-grade gliomas. Future Oncol. 2013, 9, 1215-1229. [CrossRef] [PubMed]

73. Faure, R.; Vincent, M.; Dufour, M.; Shaver, A.; Posner, B.I. Arrest at the G2/M transition of the cell cycle by protein-tyrosine phosphatase inhibition: Studies on a neuronal and a glial cell line. J. Cell. Biochem. 1995, 59, 389-401. [CrossRef] [PubMed]

74. Scrivens, P.J.; Alaoui-Jamali, M.A.; Giannini, G.; Wang, T.; Loignon, M.; Batist, G.; Sandor, V.A. Cdc25A-inhibitory properties and antineoplastic activity of bisperoxovanadium analogues. Mol. Cancer Ther. 2003, 2, 1053-1059. [PubMed]

75. Spinelli, L.; Lindsay, Y.E.; Leslie, N.R. PTEN inhibitors: An evaluation of current compounds. Adv. Biol. Regul. 2015, 57, 102-111. [CrossRef] [PubMed]

76. Zhang, Q.G.; Wu, D.N.; Han, D.; Zhang, G.Y. Critical role of PTEN in the coupling between PI3K/Akt and JNK1/2 signaling in ischemic brain injury. FEBS Lett. 2007, 581, 495-505. [CrossRef] [PubMed]

77. Yang, P.; Dankowski, A.; Hagg, T. Protein tyrosine phosphatase inhibition reduces degeneration of dopaminergic substantia nigra neurons and projections in 6-OHDA treated adult rats. Eur. J. Neurosci. 2007, 25, 1332-1340. [CrossRef] [PubMed]

78. Nakashima, S.; Arnold, S.A.; Mahoney, E.T.; Sithu, S.D.; Zhang, Y.P.; D'Souza, S.E.; Shields, C.B.; Hagg, T. Small-molecule protein tyrosine phosphatase inhibition as a neuroprotective treatment after spinal cord injury in adult rats. J. Neurosci. 2008, 28, 7293-7303. [CrossRef] [PubMed]

79. Li, D.; Qu, Y.; Mao, M.; Zhang, X.; Li, J.; Ferriero, D.; Mu, D. Involvement of the PTEN-AKT-FOXO3a pathway in neuronal apoptosis in developing rat brain after hypoxia-ischemia. J. Cereb. Blood Flow Metab. 2009, 29, 1903-1913. [CrossRef] [PubMed]

80. Christie, K.J.; Webber, C.A.; Martinez, J.A.; Singh, B.; Zochodne, D.W. PTEN inhibition to facilitate intrinsic regenerative outgrowth of adult peripheral axons. J. Neurosci. 2010, 30, 9306-9315. [CrossRef] [PubMed]

81. Shi, G.D.; OuYang, Y.P.; Shi, J.G.; Liu, Y.; Yuan, W.; Jia, L.S. PTEN deletion prevents ischemic brain injury by activating the mTOR signaling pathway. Biochem. Biophys. Res. Commun. 2011, 404, 941-945. [CrossRef] [PubMed]

82. Walker, C.L.; Walker, M.J.; Liu, N.K.; Risberg, E.C.; Gao, X.; Chen, J.; Xu, X.M. Systemic bisperoxovanadium activates Akt/mTOR, reduces autophagy, and enhances recovery following cervical spinal cord injury. PLoS ONE 2012, 7, e30012. [CrossRef] [PubMed]

83. Walker, C.L.; Wang, X.; Bullis, C.; Liu, N.K.; Lu, Q.; Fry, C.; Deng, L.; Xu, X.M. Biphasic bisperoxovanadium administration and Schwann cell transplantation for repair after cervical contusive spinal cord injury. Exp. Neurol. 2015, 264, 163-172. [CrossRef] [PubMed]

84. Walker, C.L.; Xu, X.M. PTEN inhibitor bisperoxovanadium protects oligodendrocytes and myelin and prevents neuronal atrophy in adult rats following cervical hemicontusive spinal cord injury. Neurosci. Lett. 2014, 573, 64-68. [CrossRef] [PubMed]

85. Zhao, J.; Qu, Y.; Wu, J.; Cao, M.; Ferriero, D.M.; Zhang, L.; Mu, D. PTEN inhibition prevents rat cortical neuron injury after hypoxia-ischemia. Neuroscience 2013, 238, 242-251. [CrossRef] [PubMed]

86. Ding, J.; Guo, J.; Yuan, Q.; Yuan, F.; Chen, H.; Tian, H. Inhibition of phosphatase and tensin homolog deleted on chromosome 10 decreases rat cortical neuron injury and blood-brain barrier permeability, and improves neurological functional recovery in traumatic brain injury model. PLoS ONE 2013, 8, e80429. [CrossRef] [PubMed] 
87. Guo, J.Y.; Ding, J.; Yuan, F.; Chen, H.; Chen, S.W.; Tian, H.L. Dose-dependent protective effect of bisperoxovanadium against acute cerebral ischemia in a rat model of ischemia/reperfusion injury. Int. J. Mol. Sci. 2013, 14, 12013-12022. [CrossRef] [PubMed]

88. Liu, Y.; Wang, L.; Long, Z.Y.; Wu, Y.M.; Wan, Q.; Jiang, J.X.; Wang, Z.G. Inhibiting PTEN protects hippocampal neurons against stretch injury by decreasing membrane translocation of AMPA receptor GluR2 subunit. PLoS ONE 2013, 8, e65431. [CrossRef] [PubMed]

89. Wyatt, L.A.; Filbin, M.T.; Keirstead, H.S. PTEN inhibition enhances neurite outgrowth in human embryonic stem cell-derived neuronal progenitor cells. J. Comp. Neurol. 2014, 522, 2741-2755. [CrossRef] [PubMed]

90. Chen, Y.; Luo, C.; Zhao, M.; Li, Q.; Hu, R.; Zhang, J.H.; Liu, Z.; Feng, H. Administration of a PTEN inhibitor BPV(pic) attenuates early brain injury via modulating AMPA receptor subunits after subarachnoid hemorrhage in rats. Neurosci. Lett. 2015, 588, 131-136. [CrossRef] [PubMed]

91. Mao, L.L.; Hao, D.L.; Mao, X.W.; Xu, Y.F.; Huang, T.T.; Wu, B.N.; Wang, L.H. Neuroprotective effects of bisperoxovanadium on cerebral ischemia by inflammation inhibition. Neurosci. Lett. 2015, 602, 120-125. [CrossRef] [PubMed]

92. Vuong, P.M.; Nguyen, H.T.; Katano, T.; Matsumura, S.; Saito, A.; Yamada, A.; Furue, H.; Ito, S. Impaired peripheral nerve regeneration in type-2 diabetic mouse model. Eur. J. Neurosci. 2017. [CrossRef]

93. Chen, Z.; Chen, B.; Xu, W.F.; Liu, R.F.; Yang, J.; Yu, C.X. Effects of PTEN inhibition on regulation of tau phosphorylation in an okadaic acid-induced neurodegeneration model. Int. J. Dev. Neurosci. 2012, 30, 411-419. [CrossRef] [PubMed]

94. Knafo, S.; Sanchez-Puelles, C.; Palomer, E.; Delgado, I.; Draffin, J.E.; Mingo, J.; Wahle, T.; Kaleka, K.; Mou, L.; Pereda-Perez, I.; et al. PTEN recruitment controls synaptic and cognitive function in Alzheimer's models. Nat. Neurosci. 2016, 19, 443-453. [CrossRef] [PubMed]

95. Cui, W.; Wang, S.; Wang, Z.; Wang, Z.; Sun, C.; Zhang, Y. Inhibition of PTEN Attenuates Endoplasmic Reticulum Stress and Apoptosis via Activation of PI3K/AKT Pathway in Alzheimer's Disease. Neurochem. Res. 2017, 42, 3052-3060. [CrossRef] [PubMed]

96. Liu, X.Y.; Zhang, L.J.; Chen, Z.; Liu, L.B. The PTEN inhibitor bpV(pic) promotes neuroprotection against amyloid beta-peptide (25-35)-induced oxidative stress and neurotoxicity. Neurol. Res. 2017, 39, 758-765. [CrossRef] [PubMed]

97. De Paula, M.L.; Cui, Q.L.; Hossain, S.; Antel, J.; Almazan, G. The PTEN inhibitor bisperoxovanadium enhances myelination by amplifying IGF-1 signaling in rat and human oligodendrocyte progenitors. Glia 2014, 62, 64-77. [CrossRef] [PubMed]

98. Wang, Y.L.; Li, F.; Chen, X. Pten Inhibitor-bpV Ameliorates Early Postnatal Propofol Exposure-Induced Memory Deficit and Impairment of Hippocampal LTP. Neurochem. Res. 2015, 40, 1593-1599. [CrossRef] [PubMed]

99. Chen, X.; Wang, W.; Zhang, J.; Li, S.; Zhao, Y.; Tan, L.; Luo, A. Involvement of caspase-3/PTEN signaling pathway in isoflurane-induced decrease of self-renewal capacity of hippocampal neural precursor cells. Brain Res. 2015, 1625, 275-286. [CrossRef] [PubMed]

100. Tan, L.; Chen, X.; Wang, W.; Zhang, J.; Li, S.; Zhao, Y.; Wang, J.; Luo, A. Pharmacological inhibition of PTEN attenuates cognitive deficits caused by neonatal repeated exposures to isoflurane via inhibition of NR2B-mediated tau phosphorylation in rats. Neuropharmacology 2017, 114, 135-145. [CrossRef] [PubMed]

101. Grande, V.; Manassero, G.; Vercelli, A. Neuroprotective and Anti-Inflammatory Roles of the Phosphatase and Tensin Homolog Deleted on Chromosome Ten (PTEN) Inhibition in a mouse model of Temporal Lobe Epilepsy. PLoS ONE 2014, 9, e114554. [CrossRef] [PubMed]

102. Sury, M.D.; Vorlet-Fawer, L.; Agarinis, C.; Yousefi, S.; Grandgirard, D.; Leib, S.L.; Christen, S. Restoration of Akt activity by the bisperoxovanadium compound $\mathrm{bpV}$ (pic) attenuates hippocampal apoptosis in experimental neonatal pneumococcal meningitis. Neurobiol. Dis. 2011, 41, 201-208. [CrossRef] [PubMed]

103. Keyes, K.T.; Xu, J.; Long, B.; Zhang, C.; Hu, Z.; Ye, Y. Pharmacological inhibition of PTEN limits myocardial infarct size and improves left ventricular function postinfarction. Am. J. Physiol. Heart Circ. Physiol. 2010, 298, H1198-H1208. [CrossRef] [PubMed]

104. Zu, L.; Shen, Z.; Wesley, J.; Cai, Z.P. PTEN inhibitors cause a negative inotropic and chronotropic effect in mice. Eur. J. Pharmacol. 2011, 650, 298-302. [CrossRef] [PubMed] 
105. Mao, L.; Jia, J.; Zhou, X.; Xiao, Y.; Wang, Y.; Mao, X.; Zhen, X.; Guan, Y.; Alkayed, N.J.; Cheng, J. Delayed administration of a PTEN inhibitor BPV improves functional recovery after experimental stroke. Neuroscience 2013, 231, 272-281. [CrossRef] [PubMed]

106. Zhu, X.; Shao, Z.H.; Li, C.; Li, J.; Zhong, Q.; Learoyd, J.; Meliton, A.; Meliton, L.; Leff, A.R.; Vanden Hoek, T.L. TAT-protein blockade during ischemia/reperfusion reveals critical role for p85 PI3K-PTEN interaction in cardiomyocyte injury. PLoS ONE 2014, 9, e95622. [CrossRef] [PubMed]

107. Li, J.; Wang, H.; Zhong, Q.; Zhu, X.; Chen, S.J.; Qian, Y.; Costakis, J.; Bunney, G.; Beiser, D.G.; Leff, A.R.; et al. A novel pharmacological strategy by PTEN inhibition for improving metabolic resuscitation and survival after mouse cardiac arrest. Am. J. Physiol. Heart Circ. Physiol. 2015, 308, H1414-H1422. [CrossRef] [PubMed]

108. Xue, R.; Lei, S.; Xia, Z.Y.; Wu, Y.; Meng, Q.; Zhan, L.; Su, W.; Liu, H.; Xu, J.; Liu, Z.; et al. Selective inhibition of PTEN preserves ischaemic post-conditioning cardioprotection in STZ-induced Type 1 diabetic rats: Role of the PI3K/Akt and JAK2/STAT3 pathways. Clin. Sci. 2016, 130, 377-392. [CrossRef] [PubMed]

109. Tian, Y.; Daoud, A.; Shang, J. Effects of bpV(pic) and bpV(phen) on H9c2 cardiomyoblasts during both hypoxia/reoxygenation and H2O2-induced injuries. Mol. Med. Rep. 2012, 5, 852-858. [PubMed]

110. Dal Ponte, C.; Alchera, E.; Follenzi, A.; Imarisio, C.; Prat, M.; Albano, E.; Carini, R. Pharmacological postconditioning protects against hepatic ischemia/reperfusion injury. Liver Transpl. 2011, 17, 474-482. [CrossRef] [PubMed]

111. Lai, J.P.; Dalton, J.T.; Knoell, D.L. Phosphatase and tensin homologue deleted on chromosome ten (PTEN) as a molecular target in lung epithelial wound repair. Br. J. Pharmacol. 2007, 152, 1172-1184. [CrossRef] [PubMed]

112. Mihai, C.; Bao, S.; Lai, J.P.; Ghadiali, S.N.; Knoell, D.L. PTEN inhibition improves wound healing in lung epithelia through changes in cellular mechanics that enhance migration. Am. J. Physiol. Lung Cell. Mol. Physiol. 2012, 302, L287-L299. [CrossRef] [PubMed]

113. Lai, J.P.; Bao, S.; Davis, I.C.; Knoell, D.L. Inhibition of the phosphatase PTEN protects mice against oleic acid-induced acute lung injury. Br. J. Pharmacol. 2009, 156, 189-200. [CrossRef] [PubMed]

114. Liu, S.; Liu, S.; Wang, X.; Zhou, J.; Cao, Y.; Wang, F.; Duan, E. The PI3K-Akt pathway inhibits senescence and promotes self-renewal of human skin-derived precursors in vitro. Aging Cell 2011, 10, 661-674. [CrossRef] [PubMed]

115. Cao, L.; Graue-Hernandez, E.O.; Tran, V.; Reid, B.; Pu, J.; Mannis, M.J.; Zhao, M. Downregulation of PTEN at corneal wound sites accelerates wound healing through increased cell migration. Investig. Ophthalmol. Vis. Sci. 2011, 52, 2272-2278. [CrossRef] [PubMed]

116. Dimchev, G.A.; Al-Shanti, N.; Stewart, C.E. Phospho-tyrosine phosphatase inhibitor Bpv(Hopic) enhances C2C12 myoblast migration in vitro. Requirement of PI3K/AKT and MAPK/ERK pathways. J. Muscle Res. Cell Motil. 2013, 34, 125-136. [CrossRef] [PubMed]

117. Mao, D.; Sun, X. Reactivation of the PI3K/Akt Signaling Pathway by the Bisperoxovanadium Compound bpV(pic) Attenuates Photoreceptor Apoptosis in Experimental Retinal Detachment. Investig. Ophthalmol. Vis. Sci. 2015, 56, 5519-5532. [CrossRef] [PubMed]

118. Zhang, J.Y.; Ma, J.; Yu, P.; Tang, G.J.; Li, C.J.; Yu, D.M.; Zhang, Q.M. Reduced beta 2 glycoprotein I prevents high glucose-induced cell death in HUVECs through miR-21/PTEN. Am. J. Transl. Res. 2017, 9, 3935-3949. [PubMed]

119. Canetti, C.; Serezani, C.H.; Atrasz, R.G.; White, E.S.; Aronoff, D.M.; Peters-Golden, M. Activation of phosphatase and tensin homolog on chromosome 10 mediates the inhibition of FcgammaR phagocytosis by prostaglandin E2 in alveolar macrophages. J. Immunol. 2007, 179, 8350-8356. [CrossRef] [PubMed]

120. Hubbard, L.L.; Wilke, C.A.; White, E.S.; Moore, B.B. PTEN limits alveolar macrophage function against Pseudomonas aeruginosa after bone marrow transplantation. Am. J. Respir. Cell Mol. Biol. 2011, 45, 1050-1058. [CrossRef] [PubMed]

121. Li, J.; Kawamura, K.; Cheng, Y.; Liu, S.; Klein, C.; Liu, S.; Duan, E.K.; Hsueh, A.J. Activation of dormant ovarian follicles to generate mature eggs. Proc. Natl. Acad. Sci. USA 2010, 107, 10280-10284. [CrossRef] [PubMed]

122. Adhikari, D.; Gorre, N.; Risal, S.; Zhao, Z.; Zhang, H.; Shen, Y.; Liu, K. The safe use of a PTEN inhibitor for the activation of dormant mouse primordial follicles and generation of fertilizable eggs. PLoS ONE 2012, 7, e39034. [CrossRef] [PubMed] 
123. Morohaku, K.; Hoshino, Y.; Sasada, H.; Sato, E. Incorporation of phosphatase inhibitor in culture prompts growth initiation of isolated non-growing oocytes. PLoS ONE 2013, 8, e77533. [CrossRef] [PubMed]

124. Kawamura, K.; Cheng, Y.; Suzuki, N.; Deguchi, M.; Sato, Y.; Takae, S.; Ho, C.H.; Kawamura, N.; Tamura, M.; Hashimoto, S.; et al. Hippo signaling disruption and Akt stimulation of ovarian follicles for infertility treatment. Proc. Natl. Acad. Sci. USA 2013, 110, 17474-17479. [CrossRef] [PubMed]

125. Suzuki, N.; Yoshioka, N.; Takae, S.; Sugishita, Y.; Tamura, M.; Hashimoto, S.; Morimoto, Y.; Kawamura, K. Successful fertility preservation following ovarian tissue vitrification in patients with primary ovarian insufficiency. Hum. Reprod. 2015, 30, 608-615. [CrossRef] [PubMed]

126. McLaughlin, M.; Kinnell, H.L.; Anderson, R.A.; Telfer, E.E. Inhibition of phosphatase and tensin homologue (PTEN) in human ovary in vitro results in increased activation of primordial follicles but compromises development of growing follicles. Mol. Hum. Reprod. 2014, 20, 736-744. [CrossRef] [PubMed]

127. Novella-Maestre, E.; Herraiz, S.; Rodriguez-Iglesias, B.; Diaz-Garcia, C.; Pellicer, A. Short-Term PTEN Inhibition Improves In Vitro Activation of Primordial Follicles, Preserves Follicular Viability, and Restores AMH Levels in Cryopreserved Ovarian Tissue from Cancer Patients. PLoS ONE 2015, 10, e0127786. [CrossRef] [PubMed]

128. Liao, J.; Marumoto, T.; Yamaguchi, S.; Okano, S.; Takeda, N.; Sakamoto, C.; Kawano, H.; Nii, T.; Miyamato, S.; Nagai, Y.; et al. Inhibition of PTEN tumor suppressor promotes the generation of induced pluripotent stem cells. Mol. Ther. 2013, 21, 1242-1250. [CrossRef] [PubMed]

129. Liu, X.; Chen, T.; Wu, Y.; Tang, Z. Role and mechanism of PTEN in adiponectin-induced osteogenesis in human bone marrow mesenchymal stem cells. Biochem. Biophys. Res. Commun. 2017, 483, 712-717. [CrossRef] [PubMed]

130. Alimonti, A.; Nardella, C.; Chen, Z.; Clohessy, J.G.; Carracedo, A.; Trotman, L.C.; Cheng, K.; Varmeh, S.; Kozma, S.C.; Thomas, G.; et al. A novel type of cellular senescence that can be enhanced in mouse models and human tumor xenografts to suppress prostate tumorigenesis. J. Clin. Investig. 2010, 120, 681-693. [CrossRef] [PubMed]

131. Augello, G.; Puleio, R.; Emma, M.R.; Cusimano, A.; Loria, G.R.; McCubrey, J.A.; Montalto, G.; Cervello, M. A PTEN inhibitor displays preclinical activity against hepatocarcinoma cells. Cell Cycle 2016, 15, 573-583. [CrossRef] [PubMed]

132. Sharma, M.D.; Shinde, R.; McGaha, T.L.; Huang, L.; Holmgaard, R.B.; Wolchok, J.D.; Mautino, M.R.; Celis, E.; Sharpe, A.H.; Francisco, L.M.; et al. The PTEN pathway in Tregs is a critical driver of the suppressive tumor microenvironment. Sci. Adv. 2015, 1, e1500845. [CrossRef] [PubMed]

133. Silva, S.R.; Zaytseva, Y.Y.; Jackson, L.N.; Lee, E.Y.; Weiss, H.L.; Bowen, K.A.; Townsend, C.M., Jr.; Evers, B.M. The effect of PTEN on serotonin synthesis and secretion from the carcinoid cell line BON. Anticancer Res. 2011, 31, 1153-1160. [PubMed]

134. Bulger, D.A.; Conley, J.; Conner, S.H.; Majumdar, G.; Solomon, S.S. Role of PTEN in TNFalpha induced insulin resistance. Biochem. Biophys. Res. Commun. 2015, 461, 533-536. [CrossRef] [PubMed]

135. Wang, D.F.; Yang, H.J.; Gu, J.Q.; Cao, Y.L.; Meng, X.; Wang, X.L.; Lin, Y.C.; Gao, M. Suppression of phosphatase and tensin homolog protects insulin-resistant cells from apoptosis. Mol. Med. Rep. 2015, 12, 2695-2700. [CrossRef] [PubMed]

136. Da Costa, R.M.; Neves, K.B.; Mestriner, F.L.; Louzada-Junior, P.; Bruder-Nascimento, T.; Tostes, R.C. TNF-alpha induces vascular insulin resistance via positive modulation of PTEN and decreased Akt/eNOS/NO signaling in high fat diet-fed mice. Cardiovasc. Diabetol. 2016, 15, 119. [CrossRef] [PubMed]

137. Suo, Z.W.; Yang, X.; Li, L.; Liu, Y.N.; Shi, L.; Hu, X.D. Inhibition of protein tyrosine phosphatases in spinal dorsal horn attenuated inflammatory pain by repressing Src signaling. Neuropharmacology 2013, 70, 122-130. [CrossRef] [PubMed]

138. Shiwarski, D.J.; Tipton, A.; Giraldo, M.D.; Schmidt, B.F.; Gold, M.S.; Pradhan, A.A.; Puthenveedu, M.A. A PTEN-Regulated Checkpoint Controls Surface Delivery of delta Opioid Receptors. J. Neurosci. 2017, 37, 3741-3752. [CrossRef] [PubMed]

139. Christie, K.J.; Zochodne, D. Peripheral axon regrowth: New molecular approaches. Neuroscience 2013, 240, 310-324. [CrossRef] [PubMed]

140. Garcia-Junco-Clemente, P.; Golshani, P. PTEN: A master regulator of neuronal structure, function, and plasticity. Commun. Integr. Biol. 2014, 7, e28358. [CrossRef] [PubMed] 
141. Knafo, S.; Esteban, J.A. PTEN: Local and Global Modulation of Neuronal Function in Health and Disease. Trends Neurosci. 2017, 40, 83-91. [CrossRef] [PubMed]

142. Ohtake, Y.; Hayat, U.; Li, S. PTEN inhibition and axon regeneration and neural repair. Neural Regen. Res. 2015, 10, 1363-1368. [PubMed]

143. Park, K.K.; Liu, K.; Hu, Y.; Kanter, J.L.; He, Z. PTEN/mTOR and axon regeneration. Exp. Neurol. 2010, 223, 45-50. [CrossRef] [PubMed]

144. Sun, Y.; Zhang, L.; Chen, Y.; Zhan, L.; Gao, Z. Therapeutic Targets for Cerebral Ischemia Based on the Signaling Pathways of the GluN2B C Terminus. Stroke 2015, 46, 2347-2353. [CrossRef] [PubMed]

145. Park, K.K.; Liu, K.; Hu, Y.; Smith, P.D.; Wang, C.; Cai, B.; Xu, B.; Connolly, L.; Kramvis, I.; Sahin, M.; et al. Promoting axon regeneration in the adult CNS by modulation of the PTEN/mTOR pathway. Science 2008, 322, 963-966. [CrossRef] [PubMed]

146. Liu, K.; Lu, Y.; Lee, J.K.; Samara, R.; Willenberg, R.; Sears-Kraxberger, I.; Tedeschi, A.; Park, K.K.; Jin, D.; Cai, B.; et al. PTEN deletion enhances the regenerative ability of adult corticospinal neurons. Nat. Neurosci. 2010, 13, 1075-1081. [CrossRef] [PubMed]

147. Danilov, C.A.; Steward, O. Conditional genetic deletion of PTEN after a spinal cord injury enhances regenerative growth of CST axons and motor function recovery in mice. Exp. Neurol. 2015, 266, 147-160. [CrossRef] [PubMed]

148. Du, K.; Zheng, S.; Zhang, Q.; Li, S.; Gao, X.; Wang, J.; Jiang, L.; Liu, K. Pten Deletion Promotes Regrowth of Corticospinal Tract Axons 1 Year after Spinal Cord Injury. J. Neurosci. 2015, 35, 9754-9763. [CrossRef] [PubMed]

149. Jin, D.; Liu, Y.; Sun, F.; Wang, X.; Liu, X.; He, Z. Restoration of skilled locomotion by sprouting corticospinal axons induced by co-deletion of PTEN and SOCS3. Nat. Commun. 2015, 6, 8074. [CrossRef] [PubMed]

150. Kurimoto, T.; Yin, Y.; Omura, K.; Gilbert, H.Y.; Kim, D.; Cen, L.P.; Moko, L.; Kugler, S.; Benowitz, L.I. Long-distance axon regeneration in the mature optic nerve: Contributions of oncomodulin, cAMP, and pten gene deletion. J. Neurosci. 2010, 30, 15654-15663. [CrossRef] [PubMed]

151. Lewandowski, G.; Steward, O. AAVshRNA-mediated suppression of PTEN in adult rats in combination with salmon fibrin administration enables regenerative growth of corticospinal axons and enhances recovery of voluntary motor function after cervical spinal cord injury. J. Neurosci. 2014, 34, 9951-9962. [CrossRef] [PubMed]

152. Little, D.; Valori, C.F.; Mutsaers, C.A.; Bennett, E.J.; Wyles, M.; Sharrack, B.; Shaw, P.J.; Gillingwater, T.H.; Azzouz, M.; Ning, K. PTEN depletion decreases disease severity and modestly prolongs survival in a mouse model of spinal muscular atrophy. Mol. Ther. 2015, 23, 270-277. [CrossRef] [PubMed]

153. Ning, K.; Drepper, C.; Valori, C.F.; Ahsan, M.; Wyles, M.; Higginbottom, A.; Herrmann, T.; Shaw, P.; Azzouz, M.; Sendtner, M. PTEN depletion rescues axonal growth defect and improves survival in SMN-deficient motor neurons. Hum. Mol. Genet. 2010, 19, 3159-3168. [CrossRef] [PubMed]

154. Singh, B.; Singh, V.; Krishnan, A.; Koshy, K.; Martinez, J.A.; Cheng, C.; Almquist, C.; Zochodne, D.W. Regeneration of diabetic axons is enhanced by selective knockdown of the PTEN gene. Brain 2014, 137, 1051-1067. [CrossRef] [PubMed]

155. Sun, F.; Park, K.K.; Belin, S.; Wang, D.; Lu, T.; Chen, G.; Zhang, K.; Yeung, C.; Feng, G.; Yankner, B.A.; et al. Sustained axon regeneration induced by co-deletion of PTEN and SOCS3. Nature 2011, 480, 372-375. [CrossRef] [PubMed]

156. Zukor, K.; Belin, S.; Wang, C.; Keelan, N.; Wang, X.; He, Z. Short hairpin RNA against PTEN enhances regenerative growth of corticospinal tract axons after spinal cord injury. J. Neurosci. 2013, 33, 15350-15361. [CrossRef] [PubMed]

157. Shim, S.S.; Stutzmann, G.E. Inhibition of Glycogen Synthase Kinase-3: An Emerging Target in the Treatment of Traumatic Brain Injury. J. Neurotrauma 2016, 33, 2065-2076. [CrossRef] [PubMed]

158. Griffin, R.J.; Moloney, A.; Kelliher, M.; Johnston, J.A.; Ravid, R.; Dockery, P.; O'Connor, R.; O’Neill, C. Activation of Akt/PKB, increased phosphorylation of Akt substrates and loss and altered distribution of Akt and PTEN are features of Alzheimer's disease pathology. J. Neurochem. 2005, 93, 105-117. [CrossRef] [PubMed]

159. Rickle, A.; Bogdanovic, N.; Volkmann, I.; Zhou, X.; Pei, J.J.; Winblad, B.; Cowburn, R.F. PTEN levels in Alzheimer's disease medial temporal cortex. Neurochem. Int. 2006, 48, 114-123. [CrossRef] [PubMed] 
160. Sonoda, Y.; Mukai, H.; Matsuo, K.; Takahashi, M.; Ono, Y.; Maeda, K.; Akiyama, H.; Kawamata, T. Accumulation of tumor-suppressor PTEN in Alzheimer neurofibrillary tangles. Neurosci. Lett. 2010, 471, 20-24. [CrossRef] [PubMed]

161. Zhang, X.; Li, F.; Bulloj, A.; Zhang, Y.W.; Tong, G.; Zhang, Z.; Liao, F.F.; Xu, H. Tumor-suppressor PTEN affects tau phosphorylation, aggregation, and binding to microtubules. FASEB J. 2006, 20, 1272-1274. [CrossRef] [PubMed]

162. Kerr, F.; Rickle, A.; Nayeem, N.; Brandner, S.; Cowburn, R.F.; Lovestone, S. PTEN, a negative regulator of PI3 kinase signalling, alters tau phosphorylation in cells by mechanisms independent of GSK-3. FEBS Lett. 2006, 580, 3121-3128. [CrossRef] [PubMed]

163. Marciniak, E.; Leboucher, A.; Caron, E.; Ahmed, T.; Tailleux, A.; Dumont, J.; Issad, T.; Gerhardt, E.; Pagesy, P.; Vileno, M.; et al. Tau deletion promotes brain insulin resistance. J. Exp. Med. 2017, 214, 2257-2269. [CrossRef] [PubMed]

164. Jurado, S.; Benoist, M.; Lario, A.; Knafo, S.; Petrok, C.N.; Esteban, J.A. PTEN is recruited to the postsynaptic terminal for NMDA receptor-dependent long-term depression. EMBO J. 2010, 29, 2827-2840. [CrossRef] [PubMed]

165. Fraser, M.M.; Bayazitov, I.T.; Zakharenko, S.S.; Baker, S.J. Phosphatase and tensin homolog, deleted on chromosome 10 deficiency in brain causes defects in synaptic structure, transmission and plasticity, and myelination abnormalities. Neuroscience 2008, 151, 476-488. [CrossRef] [PubMed]

166. Goebbels, S.; Oltrogge, J.H.; Kemper, R.; Heilmann, I.; Bormuth, I.; Wolfer, S.; Wichert, S.P.; Mobius, W.; Liu, X.; Lappe-Siefke, C.; et al. Elevated phosphatidylinositol 3,4,5-trisphosphate in glia triggers cell-autonomous membrane wrapping and myelination. J. Neurosci. 2010, 30, 8953-8964. [CrossRef] [PubMed]

167. Harrington, E.P.; Zhao, C.; Fancy, S.P.; Kaing, S.; Franklin, R.J.; Rowitch, D.H. Oligodendrocyte PTEN is required for myelin and axonal integrity, not remyelination. Ann. Neurol. 2010, 68, 703-716. [CrossRef] [PubMed]

168. Maire, C.L.; Ramkissoon, S.; Hayashi, M.; Haidar, S.; Ramkissoon, L.; DiTomaso, E.; Ligon, K.L. Pten loss in Olig2 expressing neural progenitor cells and oligodendrocytes leads to interneuron dysplasia and leukodystrophy. Stem Cells 2014, 32, 313-326. [CrossRef] [PubMed]

169. Goebbels, S.; Wieser, G.L.; Pieper, A.; Spitzer, S.; Weege, B.; Yan, K.; Edgar, J.M.; Yagensky, O.; Wichert, S.P.; Agarwal, A.; et al. A neuronal PI(3,4,5)P3-dependent program of oligodendrocyte precursor recruitment and myelination. Nat. Neurosci. 2017, 20, 10-15. [CrossRef] [PubMed]

170. Sahin, E.; Brunner, J.S.; Kral, J.B.; Kuttke, M.; Hanzl, L.; Datler, H.; Paar, H.; Neuwinger, N.; Saferding, V.; Zinser, E.; et al. Loss of Phosphatase and Tensin Homolog in APCs Impedes Th17-Mediated Autoimmune Encephalomyelitis. J. Immunol. 2015, 195, 2560-2570. [CrossRef] [PubMed]

171. Yu, D.; Li, L.; Yuan, W. Neonatal anesthetic neurotoxicity: Insight into the molecular mechanisms of long-term neurocognitive deficits. Biomed. Pharmacother. 2017, 87, 196-199. [CrossRef] [PubMed]

172. Adachi, T.; Takigawa, H.; Nomura, T.; Watanabe, Y.; Kowa, H. Cowden Syndrome with a Novel PTEN Mutation Presenting with Partial Epilepsy Related to Focal Cortical Dysplasia. Intern. Med. 2017. [CrossRef] [PubMed]

173. Cheung, K.M.; Lam, C.W.; Chan, Y.K.; Siu, W.K.; Yong, L. Atypical focal cortical dysplasia in a patient with Cowden syndrome. Hong Kong Med. J. 2014, 20, 165-167. [CrossRef] [PubMed]

174. Child, N.D.; Cascino, G.D. Mystery case: Cowden syndrome presenting with partial epilepsy related to focal cortical dysplasia. Neurology 2013, 81, e98-e99. [CrossRef] [PubMed]

175. Conti, S.; Condo, M.; Posar, A.; Mari, F.; Resta, N.; Renieri, A.; Neri, I.; Patrizi, A.; Parmeggiani, A. Phosphatase and tensin homolog (PTEN) gene mutations and autism: Literature review and a case report of a patient with Cowden syndrome, autistic disorder, and epilepsy. J. Child Neurol. 2012, 27, 392-397. [CrossRef] [PubMed]

176. Elia, M.; Amato, C.; Bottitta, M.; Grillo, L.; Calabrese, G.; Esposito, M.; Carotenuto, M. An atypical patient with Cowden syndrome and PTEN gene mutation presenting with cortical malformation and focal epilepsy. Brain Dev. 2012, 34, 873-876. [CrossRef] [PubMed]

177. Citraro, R.; Leo, A.; Constanti, A.; Russo, E.; De Sarro, G. mTOR pathway inhibition as a new therapeutic strategy in epilepsy and epileptogenesis. Pharmacol. Res. 2016, 107, 333-343. [CrossRef] [PubMed]

178. Kalogeris, T.; Baines, C.P.; Krenz, M.; Korthuis, R.J. Cell biology of ischemia/reperfusion injury. Int. Rev. Cell Mol. Biol. 2012, 298, 229-317. [PubMed] 
179. Mocanu, M.M.; Yellon, D.M. PTEN, the Achilles' heel of myocardial ischaemia/reperfusion injury? Br. J. Pharmacol. 2007, 150, 833-838. [CrossRef] [PubMed]

180. Cai, Z.; Semenza, G.L. PTEN activity is modulated during ischemia and reperfusion: Involvement in the induction and decay of preconditioning. Circ. Res. 2005, 97, 1351-1359. [CrossRef] [PubMed]

181. Parajuli, N.; Yuan, Y.; Zheng, X.; Bedja, D.; Cai, Z.P. Phosphatase PTEN is critically involved in post-myocardial infarction remodeling through the Akt/interleukin-10 signaling pathway. Basic Res. Cardiol. 2012, 107, 248. [CrossRef] [PubMed]

182. Siddall, H.K.; Warrell, C.E.; Yellon, D.M.; Mocanu, M.M. Ischemia-reperfusion injury and cardioprotection: Investigating PTEN, the phosphatase that negatively regulates PI3K, using a congenital model of PTEN haploinsufficiency. Basic Res. Cardiol. 2008, 103, 560-568. [CrossRef] [PubMed]

183. Crackower, M.A.; Oudit, G.Y.; Kozieradzki, I.; Sarao, R.; Sun, H.; Sasaki, T.; Hirsch, E.; Suzuki, A.; Shioi, T.; Irie-Sasaki, J.; et al. Regulation of myocardial contractility and cell size by distinct PI3K-PTEN signaling pathways. Cell 2002, 110, 737-749. [CrossRef]

184. Oudit, G.Y.; Kassiri, Z.; Zhou, J.; Liu, Q.C.; Liu, P.P.; Backx, P.H.; Dawood, F.; Crackower, M.A.; Scholey, J.W.; Penninger, J.M. Loss of PTEN attenuates the development of pathological hypertrophy and heart failure in response to biomechanical stress. Cardiovasc. Res. 2008, 78, 505-514. [CrossRef] [PubMed]

185. Roe, N.D.; Xu, X.; Kandadi, M.R.; Hu, N.; Pang, J.; Weiser-Evans, M.C.; Ren, J. Targeted deletion of PTEN in cardiomyocytes renders cardiac contractile dysfunction through interruption of Pink1-AMPK signaling and autophagy. Biochim. Biophys. Acta 2015, 1852, 290-298. [CrossRef] [PubMed]

186. Yue, S.; Rao, J.; Zhu, J.; Busuttil, R.W.; Kupiec-Weglinski, J.W.; Lu, L.; Wang, X.; Zhai, Y. Myeloid PTEN deficiency protects livers from ischemia reperfusion injury by facilitating M2 macrophage differentiation. J. Immunol. 2014, 192, 5343-5353. [CrossRef] [PubMed]

187. Zhou, J.; Fan, Y.; Tang, S.; Wu, H.; Zhong, J.; Huang, Z.; Yang, C.; Chen, H. Inhibition of PTEN activity aggravates cisplatin-induced acute kidney injury. Oncotarget 2017, 8, 103154-103166. [CrossRef] [PubMed]

188. Zhou, J.; Jia, L.; Hu, Z.; Wang, Y. Pharmacological Inhibition of PTEN Aggravates Acute Kidney Injury. Sci. Rep. 2017, 7, 9503. [CrossRef] [PubMed]

189. Hu, Z.; Wang, H.; Lee, I.H.; Modi, S.; Wang, X.; Du, J.; Mitch, W.E. PTEN inhibition improves muscle regeneration in mice fed a high-fat diet. Diabetes 2010, 59, 1312-1320. [CrossRef] [PubMed]

190. Squarize, C.H.; Castilho, R.M.; Bugge, T.H.; Gutkind, J.S. Accelerated wound healing by mTOR activation in genetically defined mouse models. PLoS ONE 2010, 5, e10643. [CrossRef] [PubMed]

191. Tiozzo, C.; de Langhe, S.; Yu, M.; Londhe, V.A.; Carraro, G.; Li, M.; Li, C.; Xing, Y.; Anderson, S.; Borok, Z.; et al. Deletion of Pten expands lung epithelial progenitor pools and confers resistance to airway injury. Am. J. Respir. Crit. Care Med. 2009, 180, 701-712. [CrossRef] [PubMed]

192. Tsugawa, K.; Jones, M.K.; Akahoshi, T.; Moon, W.S.; Maehara, Y.; Hashizume, M.; Sarfeh, I.J.; Tarnawski, A.S. Abnormal PTEN expression in portal hypertensive gastric mucosa: A key to impaired PI 3-kinase/Akt activation and delayed injury healing? FASEB J. 2003, 17, 2316-2318. [CrossRef] [PubMed]

193. Zhao, M.; Song, B.; Pu, J.; Wada, T.; Reid, B.; Tai, G.; Wang, F.; Guo, A.; Walczysko, P.; Gu, Y.; et al. Electrical signals control wound healing through phosphatidylinositol-3-OH kinase-gamma and PTEN. Nature 2006, 442, 457-460. [CrossRef] [PubMed]

194. Flodby, P.; Liebler, J.M.; Sunohara, M.; Castillo, D.R.; McConnell, A.M.; Krishnaveni, M.S.; Banfalvi, A.; Li, M.; Stripp, B.; Zhou, B.; et al. Region-specific role for Pten in maintenance of epithelial phenotype and integrity. Am. J. Physiol. Lung Cell. Mol. Physiol. 2017, 312, L131-L142. [CrossRef] [PubMed]

195. Leslie, N.R.; Maccario, H.; Spinelli, L.; Davidson, L. The significance of PTEN's protein phosphatase activity. Adv. Enzyme Regul. 2009, 49, 190-196. [CrossRef] [PubMed]

196. Cao, X.; Wei, G.; Fang, H.; Guo, J.; Weinstein, M.; Marsh, C.B.; Ostrowski, M.C.; Tridandapani, S. The inositol 3-phosphatase PTEN negatively regulates Fc gamma receptor signaling, but supports Toll-like receptor 4 signaling in murine peritoneal macrophages. J. Immunol. 2004, 172, 4851-4857. [CrossRef] [PubMed]

197. Li, Y.; Jia, Y.; Pichavant, M.; Loison, F.; Sarraj, B.; Kasorn, A.; You, J.; Robson, B.E.; Umetsu, D.T.; Mizgerd, J.P.; et al. Targeted deletion of tumor suppressor PTEN augments neutrophil function and enhances host defense in neutropenia-associated pneumonia. Blood 2009, 113, 4930-4941. [CrossRef] [PubMed] 
198. Subramanian, K.K.; Jia, Y.; Zhu, D.; Simms, B.T.; Jo, H.; Hattori, H.; You, J.; Mizgerd, J.P.; Luo, H.R. Tumor suppressor PTEN is a physiologic suppressor of chemoattractant-mediated neutrophil functions. Blood 2007, 109, 4028-4037. [CrossRef] [PubMed]

199. Jagarlamudi, K.; Liu, L.; Adhikari, D.; Reddy, P.; Idahl, A.; Ottander, U.; Lundin, E.; Liu, K. Oocyte-specific deletion of Pten in mice reveals a stage-specific function of PTEN/PI3K signaling in oocytes in controlling follicular activation. PLoS ONE 2009, 4, e6186. [CrossRef] [PubMed]

200. Reddy, P.; Liu, L.; Adhikari, D.; Jagarlamudi, K.; Rajareddy, S.; Shen, Y.; Du, C.; Tang, W.; Hamalainen, T.; Peng, S.L.; et al. Oocyte-specific deletion of Pten causes premature activation of the primordial follicle pool. Science 2008, 319, 611-613. [CrossRef] [PubMed]

201. Fan, H.Y.; Liu, Z.; Cahill, N.; Richards, J.S. Targeted disruption of Pten in ovarian granulosa cells enhances ovulation and extends the life span of luteal cells. Mol. Endocrinol. 2008, 22, 2128-2140. [CrossRef] [PubMed]

202. Lerer-Serfaty, G.; Samara, N.; Fisch, B.; Shachar, M.; Kossover, O.; Seliktar, D.; Ben-Haroush, A.; Abir, R. Attempted application of bioengineered/biosynthetic supporting matrices with phosphatidylinositol-trisphosphate-enhancing substances to organ culture of human primordial follicles. J. Assist. Reprod. Genet. 2013, 30, 1279-1288. [CrossRef] [PubMed]

203. Lan, Z.J.; Krause, M.S.; Redding, S.D.; Li, X.; Wu, G.Z.; Zhou, H.X.; Bohler, H.C.; Ko, C.; Cooney, A.J.; Zhou, J.; et al. Selective deletion of Pten in theca-interstitial cells leads to androgen excess and ovarian dysfunction in mice. Mol. Cell. Endocrinol. 2017, 444, 26-37. [CrossRef] [PubMed]

204. Ciuffreda, L.; Falcone, I.; Incani, U.C.; Del Curatolo, A.; Conciatori, F.; Matteoni, S.; Vari, S.; Vaccaro, V.; Cognetti, F.; Milella, M. PTEN expression and function in adult cancer stem cells and prospects for therapeutic targeting. Adv. Biol. Regul. 2014, 56, 66-80. [CrossRef] [PubMed]

205. Hill, R.; Wu, H. PTEN, stem cells, and cancer stem cells. J. Biol. Chem. 2009, 284, 11755-11759. [CrossRef] [PubMed]

206. Alva, J.A.; Lee, G.E.; Escobar, E.E.; Pyle, A.D. Phosphatase and tensin homolog regulates the pluripotent state and lineage fate choice in human embryonic stem cells. Stem Cells 2011, 29, 1952-1962. [CrossRef] [PubMed]

207. Kuijk, E.W.; van Mil, A.; Brinkhof, B.; Penning, L.C.; Colenbrander, B.; Roelen, B.A. PTEN and TRP53 independently suppress Nanog expression in spermatogonial stem cells. Stem Cells Dev. 2010, 19, 979-988. [CrossRef] [PubMed]

208. He, X.; Cao, Y.; Wang, L.; Han, Y.; Zhong, X.; Zhou, G.; Cai, Y.; Zhang, H.; Gao, P. Human fibroblast reprogramming to pluripotent stem cells regulated by the miR19a/b-PTEN axis. PLoS ONE 2014, 9, e95213. [CrossRef] [PubMed]

209. Burgers, T.A.; Hoffmann, M.F.; Collins, C.J.; Zahatnansky, J.; Alvarado, M.A.; Morris, M.R.; Sietsema, D.L.; Mason, J.J.; Jones, C.B.; Ploeg, H.L.; et al. Mice lacking pten in osteoblasts have improved intramembranous and late endochondral fracture healing. PLoS ONE 2013, 8, e63857. [CrossRef] [PubMed]

210. Liu, X.; Bruxvoort, K.J.; Zylstra, C.R.; Liu, J.; Cichowski, R.; Faugere, M.C.; Bouxsein, M.L.; Wan, C.; Williams, B.O.; Clemens, T.L. Lifelong accumulation of bone in mice lacking Pten in osteoblasts. Proc. Natl. Acad. Sci. USA 2007, 104, 2259-2264. [CrossRef] [PubMed]

211. Chen, Z.; Trotman, L.C.; Shaffer, D.; Lin, H.K.; Dotan, Z.A.; Niki, M.; Koutcher, J.A.; Scher, H.I.; Ludwig, T.; Gerald, W.; et al. Crucial role of p53-dependent cellular senescence in suppression of Pten-deficient tumorigenesis. Nature 2005, 436, 725-730. [CrossRef] [PubMed]

212. Lee, J.J.; Kim, B.C.; Park, M.J.; Lee, Y.S.; Kim, Y.N.; Lee, B.L.; Lee, J.S. PTEN status switches cell fate between premature senescence and apoptosis in glioma exposed to ionizing radiation. Cell Death Differ. 2011, 18, 666-677. [CrossRef] [PubMed]

213. Huynh, A.; DuPage, M.; Priyadharshini, B.; Sage, P.T.; Quiros, J.; Borges, C.M.; Townamchai, N.; Gerriets, V.A.; Rathmell, J.C.; Sharpe, A.H.; et al. Control of PI(3) kinase in Treg cells maintains homeostasis and lineage stability. Nat. Immunol. 2015, 16, 188-196. [CrossRef] [PubMed]

214. Shrestha, S.; Yang, K.; Guy, C.; Vogel, P.; Neale, G.; Chi, H. Treg cells require the phosphatase PTEN to restrain TH1 and TFH cell responses. Nat. Immunol. 2015, 16, 178-187. [CrossRef] [PubMed] 
215. Dong, Y.; Richards, J.A.; Gupta, R.; Aung, P.P.; Emley, A.; Kluger, Y.; Dogra, S.K.; Mahalingam, M.; Wajapeyee, N. PTEN functions as a melanoma tumor suppressor by promoting host immune response. Oncogene 2014, 33, 4632-4642. [CrossRef] [PubMed]

216. Silva, S.R.; Bowen, K.A.; Rychahou, P.G.; Jackson, L.N.; Weiss, H.L.; Lee, E.Y.; Townsend, C.M., Jr.; Evers, B.M. VEGFR-2 expression in carcinoid cancer cells and its role in tumor growth and metastasis. Int. J. Cancer. 2011, 128, 1045-1056. [CrossRef] [PubMed]

217. Lazar, D.F.; Saltiel, A.R. Lipid phosphatases as drug discovery targets for type 2 diabetes. Nat. Rev. Drug Discov. 2006, 5, 333-342. [CrossRef] [PubMed]

218. Li, A.; Qiu, M.; Zhou, H.; Wang, T.; Guo, W. PTEN, Insulin Resistance and Cancer. Curr. Pharm. Des. 2017, 23, 3667-3676. [CrossRef] [PubMed]

219. Kurlawalla-Martinez, C.; Stiles, B.; Wang, Y.; Devaskar, S.U.; Kahn, B.B.; Wu, H. Insulin hypersensitivity and resistance to streptozotocin-induced diabetes in mice lacking PTEN in adipose tissue. Mol. Cell. Biol. 2005, 25, 2498-2510. [CrossRef] [PubMed]

220. Stiles, B.L.; Kuralwalla-Martinez, C.; Guo, W.; Gregorian, C.; Wang, Y.; Tian, J.; Magnuson, M.A.; Wu, H. Selective deletion of Pten in pancreatic beta cells leads to increased islet mass and resistance to STZ-induced diabetes. Mol. Cell. Biol. 2006, 26, 2772-2781. [CrossRef] [PubMed]

221. Wang, L.; Liu, Y.; Lu, S.Y.; Nguyen, K.T.; Schroer, S.A.; Suzuki, A.; Mak, T.W.; Gaisano, H.; Woo, M. Deletion of Pten in pancreatic ss-cells protects against deficient ss-cell mass and function in mouse models of type 2 diabetes. Diabetes 2010, 59, 3117-3126. [CrossRef] [PubMed]

222. Wijesekara, N.; Konrad, D.; Eweida, M.; Jefferies, C.; Liadis, N.; Giacca, A.; Crackower, M.; Suzuki, A.; Mak, T.W.; Kahn, C.R.; et al. Muscle-specific Pten deletion protects against insulin resistance and diabetes. Mol. Cell. Biol. 2005, 25, 1135-1145. [CrossRef] [PubMed]

223. Butler, M.G.; Dasouki, M.J.; Zhou, X.P.; Talebizadeh, Z.; Brown, M.; Takahashi, T.N.; Miles, J.H.; Wang, C.H.; Stratton, R.; Pilarski, R.; et al. Subset of individuals with autism spectrum disorders and extreme macrocephaly associated with germline PTEN tumour suppressor gene mutations. J. Med. Genet. 2005, 42, 318-321. [CrossRef] [PubMed]

224. Lo, Y.T.; Tzeng, T.F.; Liu, I.M. Role of tumor suppressor PTEN in tumor necrosis factor alpha-induced inhibition of insulin signaling in murine skeletal muscle C2C12 cells. Horm. Metab. Res. 2007, 39, 173-178. [CrossRef] [PubMed]

225. Qin, G.; Fan, X.; Chen, L.; Shen, C.; Gui, B.; Tan, G.; Zhou, J. Preventive effects of AdR-siPTEN through the regulation of NMDA receptor NR2B subunit in trigeminal ganglia of migraine rats. Neurol. Res. 2012, 34, 998-1006. [CrossRef] [PubMed]

226. Qin, G.; Xie, J.; Chen, L.; Wu, B.; Gui, B.; Zhou, J. PTEN inhibition preserves trigeminal nucleus caudalis neuron activation through tyrosine phosphorylation of the NR2B subunit at Tyr1472 of the NMDA receptor in a rat model of recurrent migraine. Neurol. Res. 2016, 38, 320-326. [CrossRef] [PubMed]

227. Huang, S.Y.; Sung, C.S.; Chen, W.F.; Chen, C.H.; Feng, C.W.; Yang, S.N.; Hung, H.C.; Chen, N.F.; Lin, P.R.; Chen, S.C.; et al. Involvement of phosphatase and tensin homolog deleted from chromosome 10 in rodent model of neuropathic pain. J. Neuroinflamm. 2015, 12, 59. [CrossRef] [PubMed]

228. Pouliot, P.; Camateros, P.; Radzioch, D.; Lambrecht, B.N.; Olivier, M. Protein tyrosine phosphatases regulate asthma development in a murine asthma model. J. Immunol. 2009, 182, 1334-1340. [CrossRef] [PubMed]

229. Kwak, Y.G.; Song, C.H.; Yi, H.K.; Hwang, P.H.; Kim, J.S.; Lee, K.S.; Lee, Y.C. Involvement of PTEN in airway hyperresponsiveness and inflammation in bronchial asthma. J. Clin. Investig. 2003, 111, 1083-1092. [CrossRef] [PubMed]

230. Lan, H.; Zhong, H.; Gao, Y.; Ren, D.; Chen, L.; Zhang, D.; Lai, W.; Xu, J.; Luo, Y. The PTEN tumor suppressor inhibits human airway smooth muscle cell migration. Int. J. Mol. Med. 2010, 26, 893-899. [PubMed]

231. Lee, K.S.; Kim, S.R.; Park, S.J.; Lee, H.K.; Park, H.S.; Min, K.H.; Jin, S.M.; Lee, Y.C. Phosphatase and tensin homolog deleted on chromosome 10 (PTEN) reduces vascular endothelial growth factor expression in allergen-induced airway inflammation. Mol. Pharmacol. 2006, 69, 1829-1839. [CrossRef] [PubMed] 
232. Lee, K.S.; Park, S.J.; Hwang, P.H.; Yi, H.K.; Song, C.H.; Chai, O.H.; Kim, J.S.; Lee, M.K.; Lee, Y.C. PPAR-gamma modulates allergic inflammation through up-regulation of PTEN. FASEB J. 2005, 19, 1033-1035. [CrossRef] [PubMed]

233. Ni, Z.; Tang, J.; Cai, Z.; Yang, W.; Zhang, L.; Chen, Q.; Zhang, L.; Wang, X. A new pathway of glucocorticoid action for asthma treatment through the regulation of PTEN expression. Respir. Res. 2011, 12, 47. [CrossRef] [PubMed]

234. Hou, S.Q.; Ouyang, M.; Brandmaier, A.; Hao, H.; Shen, W.H. PTEN in the maintenance of genome integrity: From DNA replication to chromosome segregation. BioEssays 2017, 39. [CrossRef] [PubMed]

(C) 2018 by the author. Licensee MDPI, Basel, Switzerland. This article is an open access article distributed under the terms and conditions of the Creative Commons Attribution (CC BY) license (http:/ / creativecommons.org/licenses/by/4.0/). 